\title{
Eriophyoid (Acariformes: Eriophyoidea) and Phytoseiid (Parasitiformes: Phytoseiidae) Mite Fauna of Selected Rubus taxa (Rosaceae) with Re-description of Anthocoptes rubicolens Roivainen and Epitrimerus rubi (Domes)
}

\author{
G. RIPKA ${ }^{1 *}$, G. KIRÁLY² and Á. SZABÓ ${ }^{3}$ \\ ${ }^{1}$ National Food Chain Safety Office, Directorate of Plant Protection, Soil Conservation and Agri-environment, \\ H-1118 Budapest, Budaörsi út 141-145, Hungary \\ ${ }^{2}$ University of Sopron, Institute of Silviculture and Forest Protection, H-9400 Sopron, Bajcsy-Zs. u. 4, Hungary \\ ${ }^{3}$ Department of Entomology, Faculty of Horticultural Science, Szent István University, \\ H-1118 Budapest, Villányi út 29-43, Hungary
}

(Received: 17 February 2020; accepted: 2 March 2020)

\begin{abstract}
Mite species (Acari: Parasitiformes, Acariformes) living on foliage of brambles (Rubus sp.) were collected in Hungary, Austria and Slovakia. Four eriophyoid mite species (Acariformes: Eriophyoidea) associated with 14 Rubus taxa were identified. Female of Anthocoptes rubicolens Roivainen, 1953 is re-described, the male is described and illustrated from Rubus praecox Bertol., and recorded for the first time from $R$. bifrons Vest, $R$. clusii Borbás, R. grabowskii Weihe, R. praecocifrons Király et Trávn., Rubus ser. Rhamnifolii (Bab.) Focke, $R$. slavonicus Király, Trávn. et Žila, and $R$. solvensis W. Maurer. Anthocoptes rubicolens is a new species for the fauna of Hungary. Female of Epitrimerus rubi (Domes, 1960) is re-described, male and nymph are described and illustrated from R. bertramii G. Braun. Morphological differences distinguishing these species from the similar Anthocoptes rubi Domes and Epitrimerus gibbosus (Nalepa) are discussed. Out of the four identified phytoseiid species, Phytoseius juvenis Wainstein et Arutunjan (Parasitiformes: Phytoseiidae) was the most frequent predatory mite on the leaves of studied Rubus spp.
\end{abstract}

Keywords: Eriophyidae, Anthocoptes, Epitrimerus, Phytoseiidae, Rubus, Rosaceae, brambles, oligophagy, Hungary, Austria, Slovakia.

The genus Rubus L. is one of the largest and most diverse groups of the plant family Rosaceae. Representatives of the genus are taxonomically intricate due to several reasons, including repeated natural hybridization, polyploidy and apomixis (Weber, 1995; Sochor et al., 2015). The approximately 800 bramble species in Europe (Kurtto et al., 2010) occur in wide scale of forest and forest-edge communities and scrubs, some of them are fruit crops or non-awaited invaders, respectively (Király, 2018).

33 eriophyoid mite species are known to occur on 31 Rubus species: Acalitus essigi (Hassan), Acalitus orthomera (Keifer), Acalitus rubensis Manson, Aceria rubicasei (Flechtmann), Aceria rubierineus (Nalepa), Aceria silvicola (Canestrini), Anthocoptes 
rubi Domes, Anthocoptes rubicolens Roivainen, Asetadiptacus acarubri Pye et de Lillo, Calepitrimerus chamaemori (Liro), Diptacus caesius Domes, Diptacus chizhouensis Wang, Xue et Hong, Diptacus gigantorubra Xin et Dong, Diptacus glaber Huang et Wang, Diptacus rubi Kuang, Diptacus rubuscolum Trinidad, Duarte et Navia, Epitrimerus gibbosus (Nalepa), Epitrimerus rubi (Domes), Epitrimerus virginiana Keifer, Epitrimerus vulgarubi Honarmand, Sadeghi-Namaghi et de Lillo, Eriophyes rubicolens (Canestrini), Eriophyes rubifolii ChannaBasavanna, Eriophyes wezaensis Smith Meyer et Ueckermann, Levonga papaitongensis Manson, Monochetus saxatilis Liro, Phyllocoptes calirubi Keifer, Phyllocoptes gracilis (Nalepa), Phyllocoptes parviflori Keifer, Phyllocoptes rubi Roivainen, Rhynacus abronius (Keifer), Trimeroptes chaetophori Mo, Zhao et Wang, Trimeroptes luanchuanensis Xue et Hong and Trimeroptes rubi Bagdasarian (Amrine and Stasny, 1994; Baker et al., 1996; Canestrini, 1892, 1894; Davis et al., 1982; Dobrivojević and Petanović, 1985; Domes, 1957, 1960, 1962, 1999; Honarmand et al., 2019; Huang, 2001; Huang and Wang, 2009; Kuang, 2001; Mo et al., 2017; Nalepa, 1890, 1891, 1892, 1895; Pye and de Lillo, 2010; Roivainen, 1950, 1953; Trinidad et al., 2018; Wang et al., 2009; Xin and Dong, 1983; Xue and Hong, 2005). Prior to this paper, no eriophyoid species have been recorded from Rubus bertramii, $R$. clusii, $R$. grabowskii, $R$. montanus, $R$. praecocifrons, $R$. praecox, $R$. slavonicus and $R$. solvensis (Amrine and Stasny, 1994; Davis et al., 1982).

The eriophyoid mite fauna of the Carpathian Basin and adjacent regions living on brambles remained grossly understudied. In Hungary, only 5 bramble-inhabiting eriophyoid species have been reported to date, e.g. Acalitus essigi (Hassan, 1928), Diptacus caesius Domes, 1999, Epitrimerus gibbosus (Nalepa, 1892), Phyllocoptes gracilis (Nalepa, 1890) and Phyllocoptes rubi Roivainen, 1950 (Farkas, 1966; Ripka, 2007; Ripka and Szendreyné, 2003), and their host connections are highly questionable because of the lack of accompanied botanical studies (Király et al., 2013).

Concerning the bramble-dwelling phytoseiid mites, some 99 species have been found worldwide (Tuovinen, 1993; Tixier et al., 2000; Salmane and Petrova, 2002; Moraes et al., 2004; McMurtry and Show, 2012; Tajmiri and Hajizadeh, 2014; Stojnić et al, 2018; Ayala-Ortega et al., 2019; Demite et al., 2020). In Central California, in a winter mite collections on wild and cultivated blackberry out of 12 identified phytoseiid species Metaseiulus arboreus (Chant) was the dominant species (McMurtry and Show, 2012). The most common species in the family Phytoseiidae that occurred on Rubus plants belong to the genera Neoseiulus and Phytoseius (Tajmiri and Hajizadeh, 2014, Demite et al. 2020). Verified occurrence of Phytoseius juvenis Wainstein et Arutunjan on Rubus species is by no means rare in Europe. P. juvenis occurs on Rubus plants growing in the wild (Tuovinen, 1993; Tixier et al., 2000; Salmane and Petrova, 2002) as part of natural vegetation not treated with plant protection products (Stojnić et al., 2018) just as on grown Rubus crops. The species in the genus Phytoseius are primarily generalist predators that live mainly on plants with pubescent leaves (McMurtry et al., 2013). In addition to their generalist feeding habits, they also prefer the consumption of various Tetranychidae species (Duso and Vettorazzo, 1999). The significant negative correlation between P. juvenis and Neotetranychus rubi Trägårdh observed on cultivated Rubus species only serves to strengthen this statement (Stojnić et al., 2018).

In Hungary a total of 12 species have been known from Rubus spp. Amblyseius andersoni (Chant) and Typhlodromus commenticius Livshitz et Kuznetzov from raspberry 
(Komlovszky and Jenser, 1987); Neoseiulus reductus (Wainstein) from Rubus caesius (Bozai, 1996); Euseius finlandicus (Oudemans), Kampimodromus aberrans (Oudemans) and Typhlodromus pyri Scheuten from blackberry (Ripka et al., 2005) were reported. Recently, Szabó et al. (2010, 2013) recorded 10 phytoseiid species, viz. Amblyseius andersoni, Anthoseius occiduus Karg, A. rhenanus (Oudemans), E. finlandicus, Neoseiulus alpinus (Schweizer), N. reductus, Phytoseius echinus Wainstein et Arutunjan, P. juvenis, P. macropilis (Banks), and T. pyri from Rubus spp. within the scope of predatory mite survey in Eger and Badacsony wine regions.

\section{Materials and Methods}

During botanical excursions in 2019 eriophyoid mites were collected by the second author (G. Király) at localities in Austria, Hungary and Slovakia from bramble (genus Rubus) specimens that showed mite damage symptoms on the foliage (e.g. erineum, leaflet deformation, yellowing and galls). The sampling covered colline and submontane deciduous forest and forest fringes, in some cases coniferous plantations, between 190 and $370 \mathrm{~m}$ a.s.l. For each locality, the geo-coordinates were determined using a Garmin GPSMAP64 handheld device in WGS 84 projection. Altogether 12 species of bramble were included in the sampling; further two distinct Rubus taxa could be identified only on the rank of series (see Tables 1, 2 and 3). The nomenclature of Rubus taxa follows generally Kurtto et al. (2010), for some recently described or lectotypified species Király et al. $(2015,2017)$ and Sochor et al., (2019). The botanical voucher specimens collected during the studies were generally deposited in the collection of the Hungarian Natural History Museum (BP) and/or in the private herbarium of G. Király.

In the course of sampling leaves of brambles were placed in paper and polythene bag and then posted to the corresponding author (G. Ripka) for identification. The leaves collected were examined under a stereo dissecting microscope (Zeiss Stemi 2000-C). All eriophyoid and phytoseiid mites were placed into $88 \%$ lactic acid with the aid of a bent insect pin. The clearing of these specimens in lactic acid took considerably longer time, about 2 months at room temperature to obtain the desired extent of clearing. The mites were mounted on microscope slides in Keifer's F-medium due to the superior contrast and longevity provided by this mounting medium (Keifer, 1975; Amrine and Manson, 1996). The slide-preparations were dried for about four weeks at room temperature and then sealed with commercial nail varnish (Upton, 1991). Specimens were examined with the aid of a compound microscope equipped with phase contrast (Nikon Eclipse E600) and a drawing tube (Nikon Y-IDT). A Zeiss Axio Imager.A2 phase-contrast microscope with differential interference contrast (DIC), connected to a computer using Axiovision image analysis software was used for making digital microscopic images on slide mounted specimens. In the supplementary descriptions of Anthocoptes rubicolens and Epitrimerus rubi, for females the measurement ranges and the mean of ten specimens, for males the measurement ranges of five specimens are given. All measurements are given in micrometers $(\mu \mathrm{m})$ and are lengths except when mentioned otherwise. Classification and terminology of external morphology follow Amrine et al. (2003) and Lindquist (1996), respectively. Phytoseiid mites were identified by the third author, Á. Szabó. 


\section{Results}

\section{Family Eriophyidae Nalepa \\ Genus Anthocoptes Nalepa \\ Anthocoptes rubicolens Roivainen, 1953}

(Figs 1-6)

Anthocoptes rubicolens Roivainen, 1953: 28. Fig. 26.

Re-description. Female - Body dirty yellow, ochre and light brown, arched or curved fusiform, $143(135-190, \mathrm{n}=10), 48$ (45-52) wide, 53 (50-60) thick. Gnathosoma 23 (21-26), projecting obliquely downwards; chelicerae 18 (15-22), dorsal palp genual setae $d 3$ (2-4), unbranched, pedipalp coxal setae ep 2 (1-2). Prodorsal shield 33 (31-35), 40 (35-45) wide, semicircular; with a subtriangular frontal lobe 5 (4-5) over gnathosomal base; shield center raised as a small medioanterior hump at anterior $1 / 3$ from frontal lobe, shield pattern composed of an incomplete, faint median line on rear $1 / 3$, two incomplete, faint and sinuous admedian lines, diverging to $1 / 2$, then converging to rear margin; two incomplete and faint submedian lines; lateral field with numerous microgranules between the submedian and the shield margin, posteriorly irregular faint granules between the tubercles of scapular setae sc. Prodorsal shield ornamentation considerably variable, e.g. number, size and position of lines, microgranules, and admedians broken on some specimens. Tubercles of scapular setae sc on rear shield margin, 22 (21-22) apart, diverging, scapular setae sc 25 (25-26), stout, directed rearwards, with a minute knob. Minute granules situated in lateral rows on epicoxal areas, i.e. laterally between shield margin and dorsal coxae of legs I and II.

Legs with all usual segments and setae present. Leg I (foreleg) 29 (26-30), femur 8 (8-9), basiventral femoral seta $b v 9(8-10)$, genu $4(4-5)$, antaxial genual seta $l$ " 19 (18-20), tibia 6 (5-7), paraxial tibial seta $l$ ' located at $1 / 3(1 / 3-1 / 4)$ from dorsal base, 5 (no range), very thin, tarsus 6 (5-6), unguinal tarsal seta $u^{\prime} 3$ (3-4), solenidion $\omega 7$ (7-8), distally rounded or with a minute knob, slightly curved, empodium simple, bilaterally symmetrical, 6 (5-6), 5-rayed.

Leg II (rear leg) 26 (24-27), femur 7 (7-8), basiventral femoral seta $b v 8$ (7-8), genu 4 (4-5), antaxial genual seta $l$ " 6 (5-7) very thin, tibia 5 (no range), tarsus 5 (5-6), unguinal tarsal seta $u^{\prime} 3(2-3)$, solenidion $\omega 7$ (7-8), distally rounded or with a minute knob, slightly curved, empodium simple, bilaterally symmetrical, 5 (5-6), 5-rayed. Tiny spinules distally on femur and genu on both leg pairs.

Coxigenital area with 4-7 faint microtuberculate semiannuli. Coxisternae I with longitudinal lines of minute granules, coxisternae II with longitudinal lines of minute granules; anterior seta on coxisternum I, seta $1 b 7$ (6-7), tubercles setae $1 b 10$ (10-11) apart, proximal seta on coxisternum I, seta $1 a 15$ (13-16), tubercles $1 a 8$ (7-8) apart, proximal seta on coxisternum II, seta $2 a 27$ (26-28), tubercles $2 a 18$ (16-20) apart. Subcapitular plate subcordate, with granules. Prosternal apodeme 6 (5-7).

Opisthosoma with 9-11 broad dorsal thanosomal semiannuli (annuli anterior to opisthosomal seta f), 2-3 narrow dorsal telosomal annuli (annuli posterior to opisthosomal seta $f$ ) and 1-2 narrow microtuberculate dorsal annuli immediately behind the rear margin of prodorsal shield, 62 (59-65) microtuberculate ventral semiannuli. Microtubercles minute and round ventrally, and oval laterally set on rear annular margin. 9-11 broad 
dorsal thanosomal semiannuli with sparsely elongate striate-like microtubercles, 2-3 dorsal telosomal annuli with tiny microtubercles. Last 4-5 annuli with linear microtubercles on ventral side. Opisthosomal setae $c 211$ (10-12), on annulus 10 (9-11); opisthosomal setae $d 37$ (28-42), on annulus 22 (21-24); opisthosomal setae $e 7$ (6-8), on annulus 36 (35-38); opisthosomal setae $f 21$ (20-22), on annulus 56 (54-60), or 5 (5-6) from the rear. Opisthosomal setae $h 254$ (52-55), very thin at apex, opisthosomal setae $h 13$ (2-3). Anal lobes normal in size and shape.

Genital plate 14 (13-17), 22 (20-25) wide. Female genital coverflap with a transverse line basally and 8-11 longitudinal ridges; coxisternal III setae $3 a 15$ (15-16) apart, 13 (12-15), very thin. (Figs 1, 2, 3, 4, 5, 6).

MALE - Similar to female, 125-139 $(n=5), 48$ wide, 45-51 thick. Gnathosoma 21-27, projecting obliquely downwards; chelicerae 17-18, dorsal palp genual setae $d 3$, unbranched, pedipalp coxal setae ep 2-3. Prodorsal shield 28-34, 35 wide, semicircular, with a subtriangular frontal lobe 3-4, shape and ornamentation similar to female. Tubercles of scapular setae $s c$ on rear shield margin, setae sc 20-22, stout, directed to the rear, with a minute knob, 24 apart. Minute granules laterally in rows between shield margin and dorsal coxae of legs I and II. Legs with all usual segments and setae present. Leg I 25-26, femur 7-8, basiventral femoral seta $b v 8-10$, genu 5, antaxial genual seta $l^{\prime \prime}$ 16-20, tibia 5, paraxial tibial seta $l^{\prime}$ located at $1 / 3$ from dorsal base, 5-6, very fine, tarsus 4-5, unguinal tarsal seta $u^{\prime} 3$, solenidion $\omega$ 6-7, slightly curved, distally rounded or with a minute knob, empodium simple, bilaterally symmetrical, 5, with 5 paired rays. Leg II 23-24, femur 7-8, basiventral femoral seta $b v 5-6$, very fine, genu 4, antaxial genual seta $l^{\prime \prime} 5-8$, very fine, tibia 4-5, tarsus 5, unguinal tarsal seta $u^{\prime} 3$, solenidion $\omega 7-8$, slightly curved, distally rounded or with a minute knob, empodium simple, bilaterally symmetrical, 5 , with 5 paired rays. Tiny spinules distally on femur and genu on both leg pairs. Coxigenital area with 4-7 faint microtuberculate semiannuli. Coxisternum I with longitudinal lines of minute granules, coxisternum II with few longitudinal lines of minute granules; anterolateral seta on coxisternum I, seta $1 b 5-6$, proximal seta on coxisternum I, seta $1 a$ 12, proximal seta on coxisternum II, seta $2 a 33$, very fine. Subcapitular plate subcordate, with granules. Prosternal apodeme 8. Opisthosoma with 8-9 broad dorsal thanosomal semiannuli (annuli anterior to opisthosomal seta $f$ ), 2-3 dorsal telosomal annuli (annuli posterior to opisthosomal seta $f$ ) and 1-2 narrow microtuberculate dorsal annuli directly behind the rear margin of prodorsal shield, 54-64 microtuberculate ventral semiannuli. 8-9 broad dorsal thanosomal semiannuli with sparsely elongate striate-like microtubercles, 2-3 narrow dorsal telosomal annuli with tiny microtubercles. Microtubercles minute and round ventrally, and oval laterally set on rear annular margin except for 3-4 ventral semiannuli of anal lobes, which elongate and linear. Anal lobes normal in size and shape. Setae $c 211-13$, on annulus 9-10; setae $d 28-40$, on annulus 19-21; setae $e$ 9-10, on annulus 31-33; setae $f$ 17-20, on annulus 49-52, or 5 from rear. Setae $h 2$ 45-55; setae $h 1$ 2-3. Genitalia 9-11, 16-17 wide, with a transverse line basally, setae 3a 12-13, 13 apart.

Host plant - Rubus praecox Bertol. (Fam. Rosaceae). The species is one of the commonest brambles in warmer regions of the Carpathian Basin, it often occurs in sunny forest fringes, including plantations, and open scrublands.

Relationship to the host - Females and males of A. rubicolens were collected from the lower surface of the leaves, from the main and secondary veins. It is a less numerous vein-sucking leaf vagrant mite, which caused no damage symptoms on the host plants. 
Locality - Hungary, Győr-Moson-Sopron County, Sopronkövesd, forest fringes along the road between Lövő and Röjtökmuzsaj, 195 m a.s.l., N47.5355, E16.8180, 14 VII 2019, G. Király.

Material examined - re-described female and described male among 3 females and 2 males on one slide, 14 July 2019, slide \# 1477. Other specimens were collected 2 slides (\# 1476a, \# 1476b) from Rubus bifrons in Sopronkövesd (Győr-Moson-Sopron county), 14 July 2019, containing 1 male, and 5 females and 2 males of Phyllocoptes gracilis, and 3 females and 1 male, and 4 females and 4 males of $P$. gracilis; 1 slide (\# 1480)

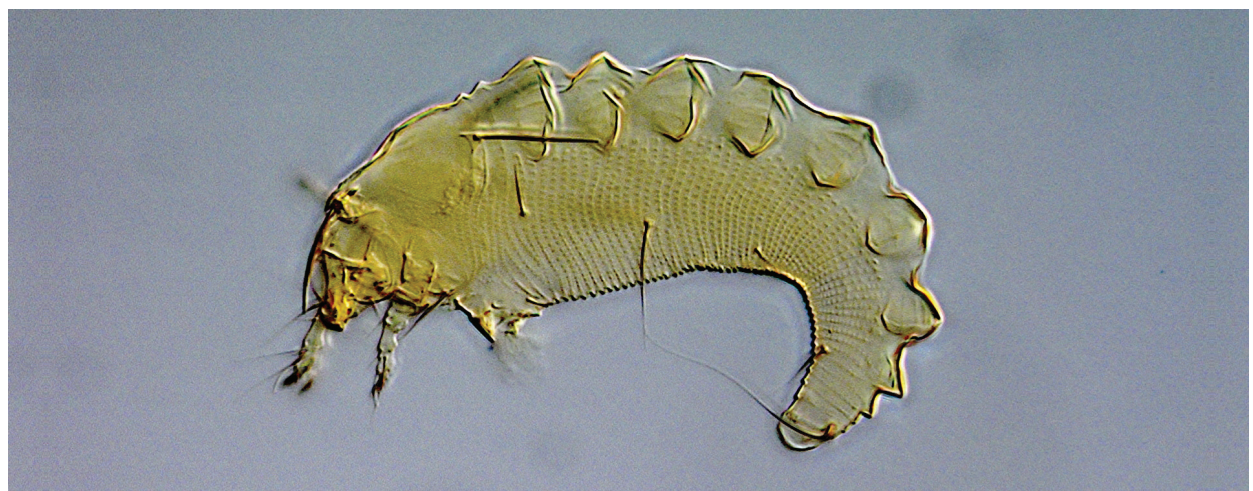

Fig. 1. Digital micrograph of Anthocoptes rubicolens, female in lateral view (Photo: Árpád Szabó)

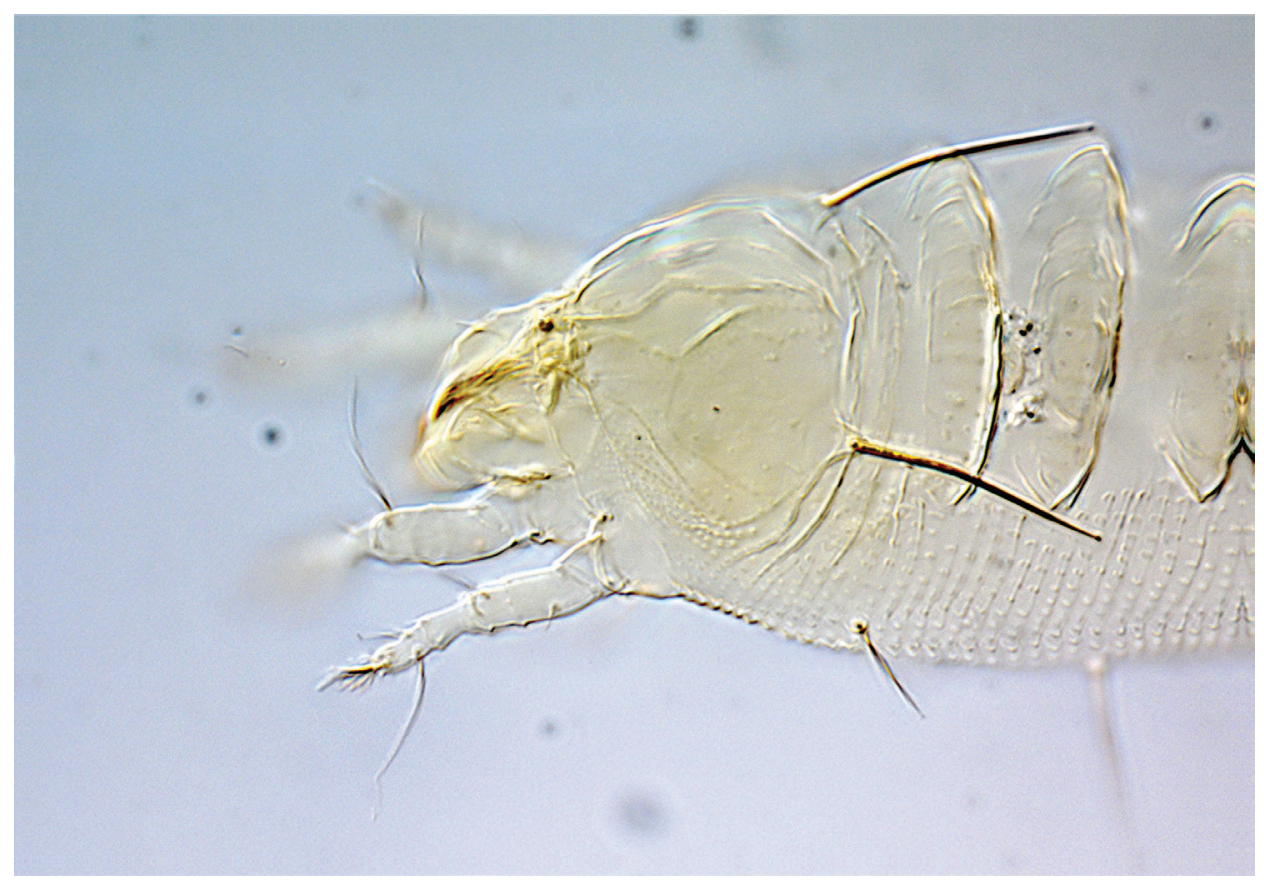

Fig. 2. Digital micrograph of Anthocoptes rubicolens, prodorsal shield and anterior opisthosoma of female in dorsolateral view (Photo: Árpád Szabó) 


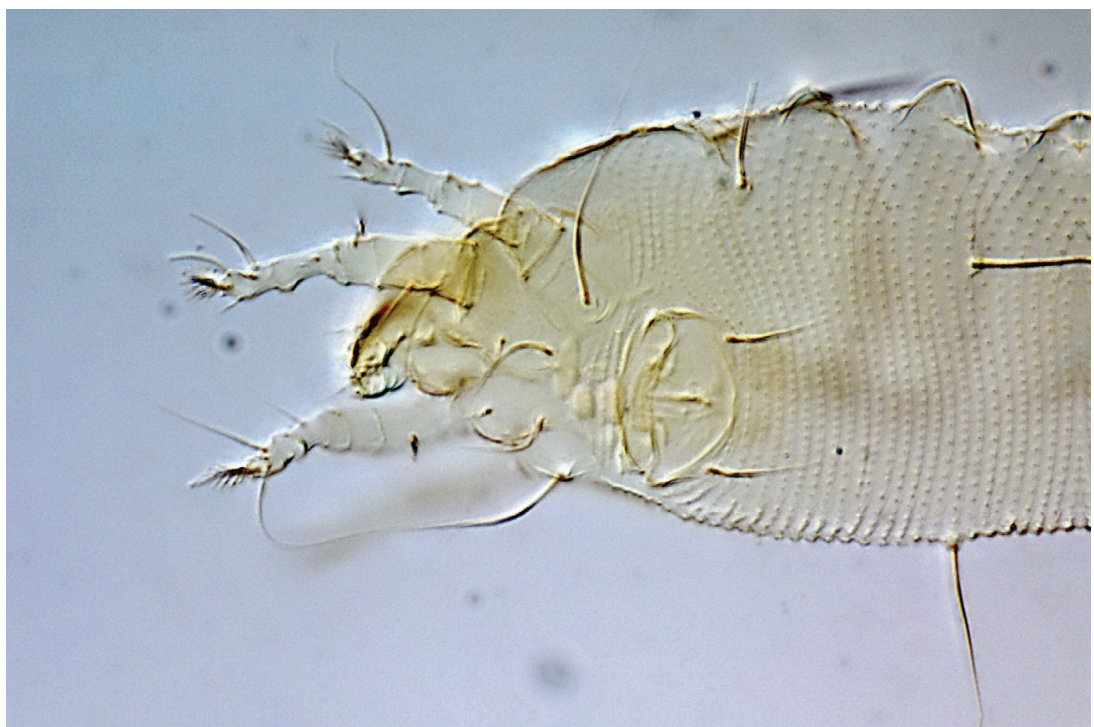

Fig. 3. Digital micrograph of Anthocoptes rubicolens, coxigenital region and legs of female (Photo: Árpád Szabó)

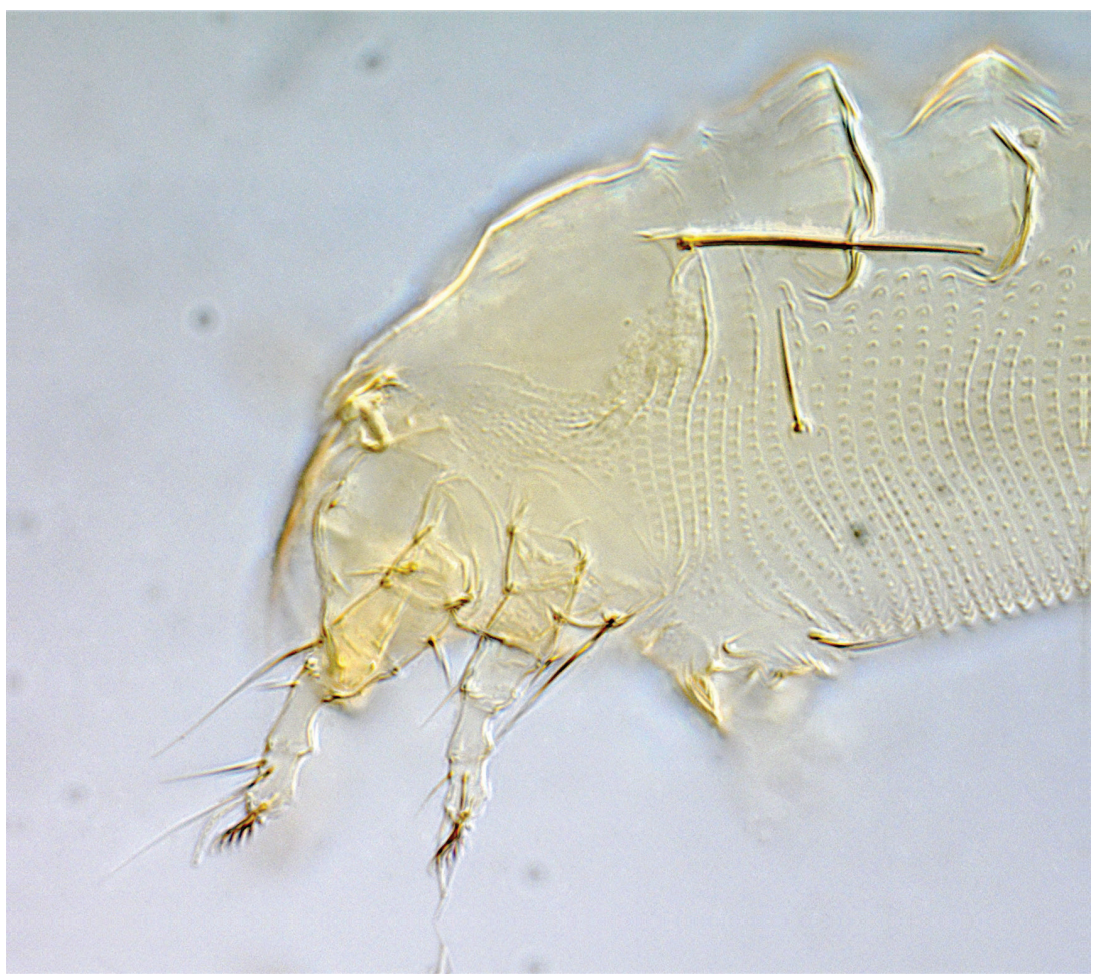

Fig. 4. Digital micrograph of Anthocoptes rubicolens, anterior part of female in lateral view (Photo: Árpád Szabó) 


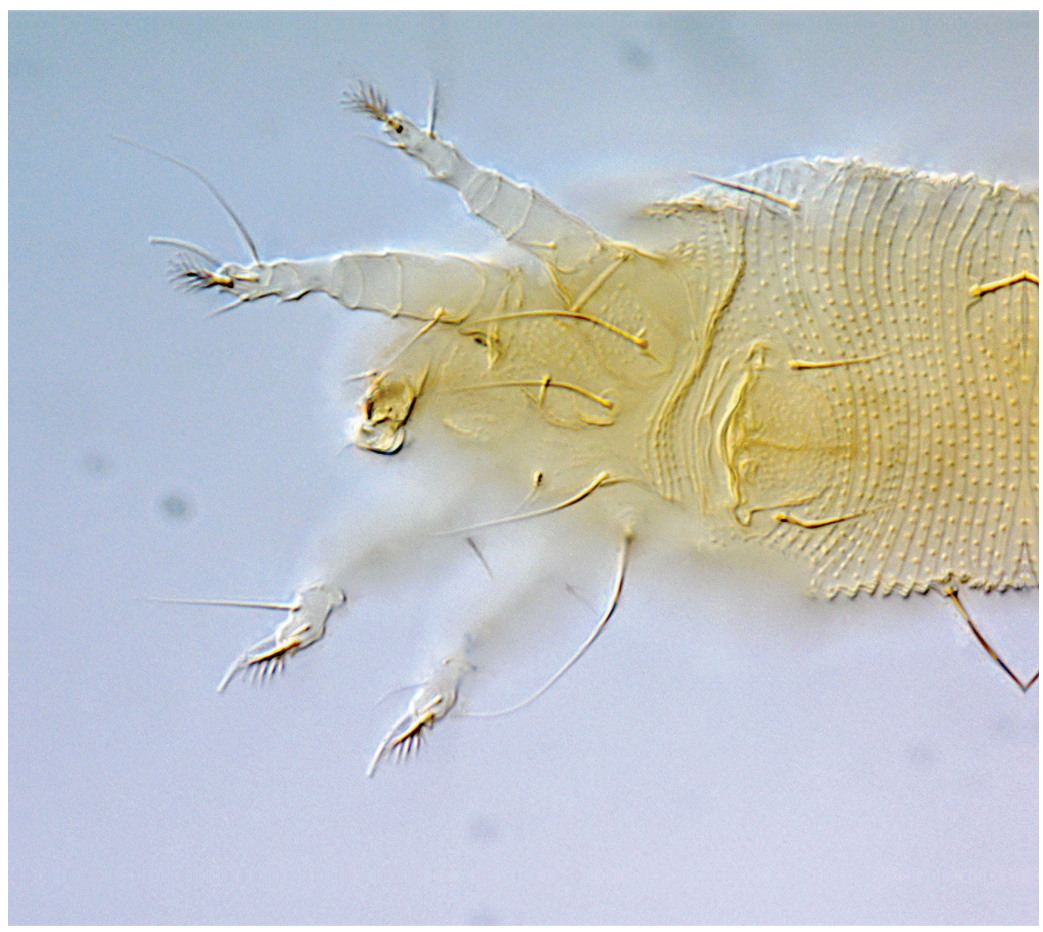

Fig. 5. Digital micrograph of Anthocoptes rubicolens, coxigenital region and legs of male (Photo: Árpád Szabó)

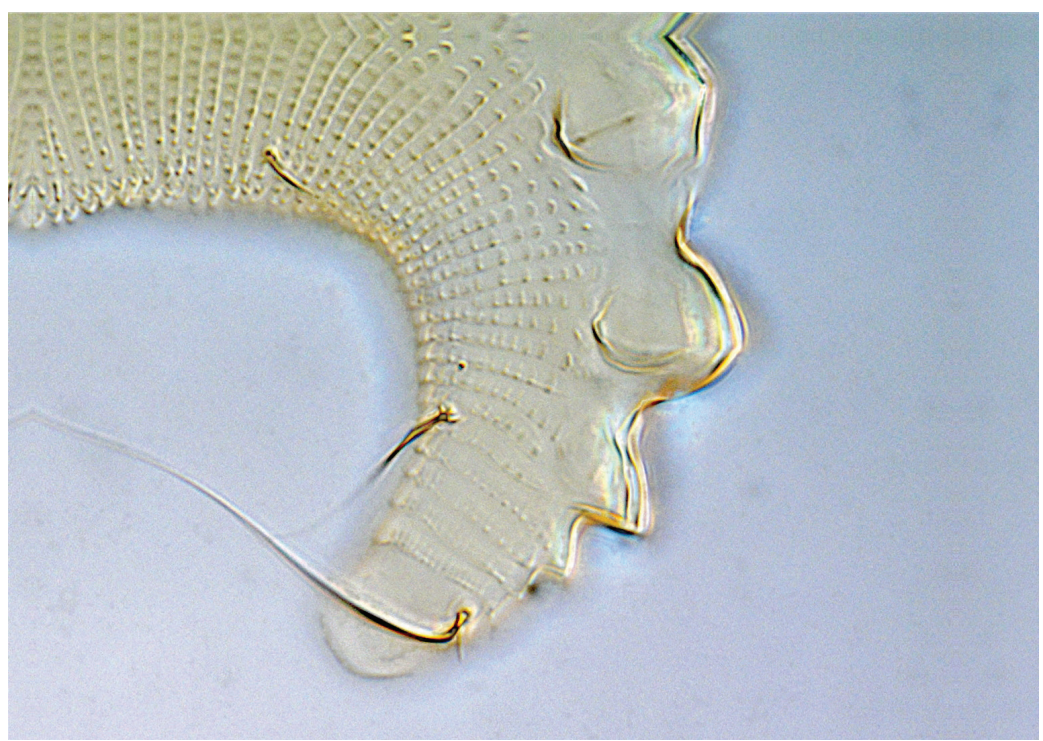

Fig. 6. Digital micrograph of Anthocoptes rubicolens, posterior part of female opisthosoma in lateral view (Photo: Árpád Szabó) 
from Rubus praecocifrons in Sopronkövesd (Győr-Moson-Sopron county), 14 July 2019, containing 1 female and 1 male; 1 slide (\# 1478) from Rubus clusii in Sopronkövesd (Győr-Moson-Sopron county), 14 July 2019, containing 1 female, and 2 females and 5 males of P. gracilis; 1 slide (\# 1481) from Rubus slavonicus in Várvölgy (Hungary, Zala county), 8 August 2019, containing 1 female and 2 males, and 4 females and 4 males of P. gracilis; 1 slide (\# 1485) from Rubus solvensis in Kétvölgy (Hungary, Vas county), 30 August 2019, containing 1 female; 2 slides (\# 1472) from Rubus clusii in Winklarn (Lower Austria), 10 July 2019, containing 1 female, and 2 females of $P$. gracilis; 2 slides (\# 1475a, \# 1475b) from Rubus grabowskii in Ansfelden (Upper Austria), 12 July 2019, containing (\# 1475a) 8 females and 3 males, and 2 females and 1 male of $P$. gracilis; (\# 1475b) 5 females and 2 males, and 1 female of $P$. gracilis; 1 slide (\# 1473) from Rubus ser. Rhamnifolii in Maria Taferl (Lower Austria), 12 July 2019, containing 2 females, and 3 females of $P$. gracilis.

These specimens were found on the underside of the leaves and are in the collection of G. Ripka and deposited in the National Food Chain Safety Office, Directorate of Plant Protection, Soil Conservation and Agri-environment, Hungary.

Roivainen (1953) described A. rubicolens from Rubus sp., collected in Basque Provinces, Spain. In the present study the vein-sucking vagrant mite was collected in Austria and Hungary from 8 bramble species (Rubus bifrons, R. clusii, R. grabowskii, $R$. praecocifrons, $R$. praecox, Rubus ser. Rhamnifolii, $R$. slavonicus and $R$. solvensis) (Table 1). A. rubicolens is a new species for the mite fauna of Hungary. Teneral females without expanded dorsal annuli mentioned by Pye and de Lillo (2010) were not collected. Another similar, European bramble-dwelling species, Anthocoptes rubi Domes, 1962 has 4-rayed empodium. Like Anthocoptes bakeri Keifer, 1959, A. rubicolens has 9-10 very broad dorsal opisthosomal annuli. However, it can be distinguished from A. bakeri by its dorsal thanosomal semiannuli with elongate striate-like microtubercles (smooth in $A$. bakeri) and coxisternae I-II with longitudinal lines of granules (smooth in A. bakeri) (Baker et al., 1996). Mixed population of eriophyoid species was frequently found. A. rubicolens co-occurred with Phyllocoptes gracilis on Rubus bifrons, R. clusii, R. grabowskii, $R$. slavonicus and $R$. solvensis in Austria and Hungary (Table 3). On R. praecox only A. rubicolens was found.

\section{Genus Epitrimerus Nalepa Epitrimerus rubi (Domes, 1960)}

(Figs 7-11)

Eriophyes rubi Domes, 1960: 245-253.

Eriophyes rubi - Davis et al., 1982: 135.

Epitrimerus rubi - Amrine and Stasny, 1994: 187, 633.

Re-description. Female - Body light ochre to light brown, fusiform, 156 (130-173, $\mathrm{n}=10), 56(55-58)$ wide, 57 (53-63) thick. Gnathosoma 20 (18-22), projecting obliquely downwards; chelicerae 15 (14-15), dorsal palp genual setae $d 6$ (6-7), unbranched, pedipalp coxal setae ep 3 (2-3). Prodorsal shield 43 (42-45), 41 (38-45) wide, semicircular; with an acuminate frontal lobe 6 (5-7) over gnathosomal base; shield pattern composed of an incomplete, faint median line on rear $1 / 3$, sometimes forked anteriorly; two incomplete, faint and slightly sinuous admedian lines, diverging to $1 / 3$, then converging to $1 / 2$, then di- 


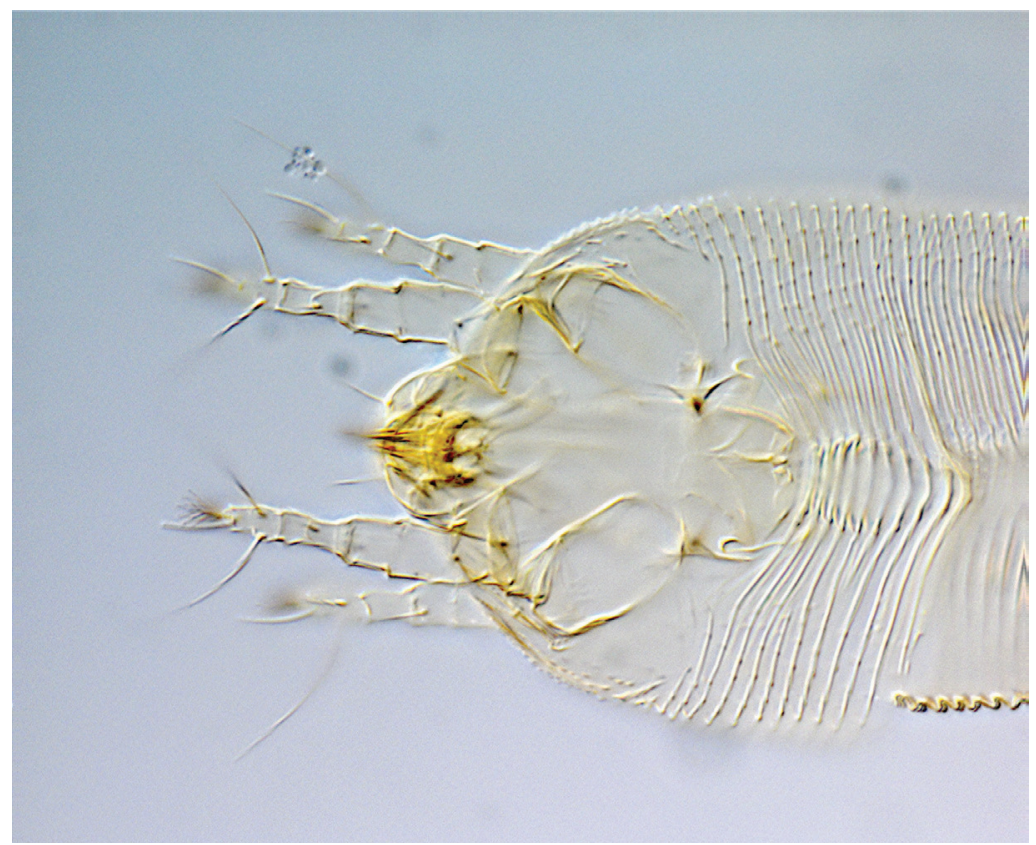

Fig. 7. Digital micrograph of Epitrimerus rubi, anterior part of female in dorsal view (Photo: Árpád Szabó)

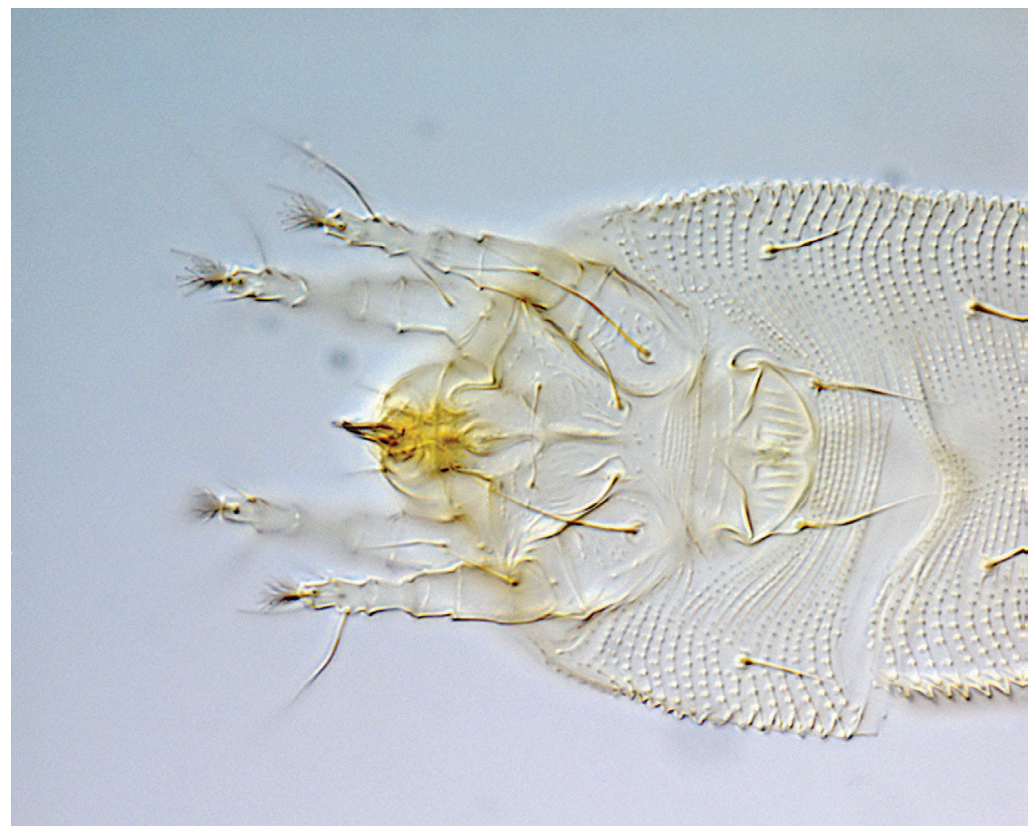

Fig. 8. Digital micrograph of Epitrimerus rubi, anterior part of female in ventral view (Photo: Árpád Szabó) 


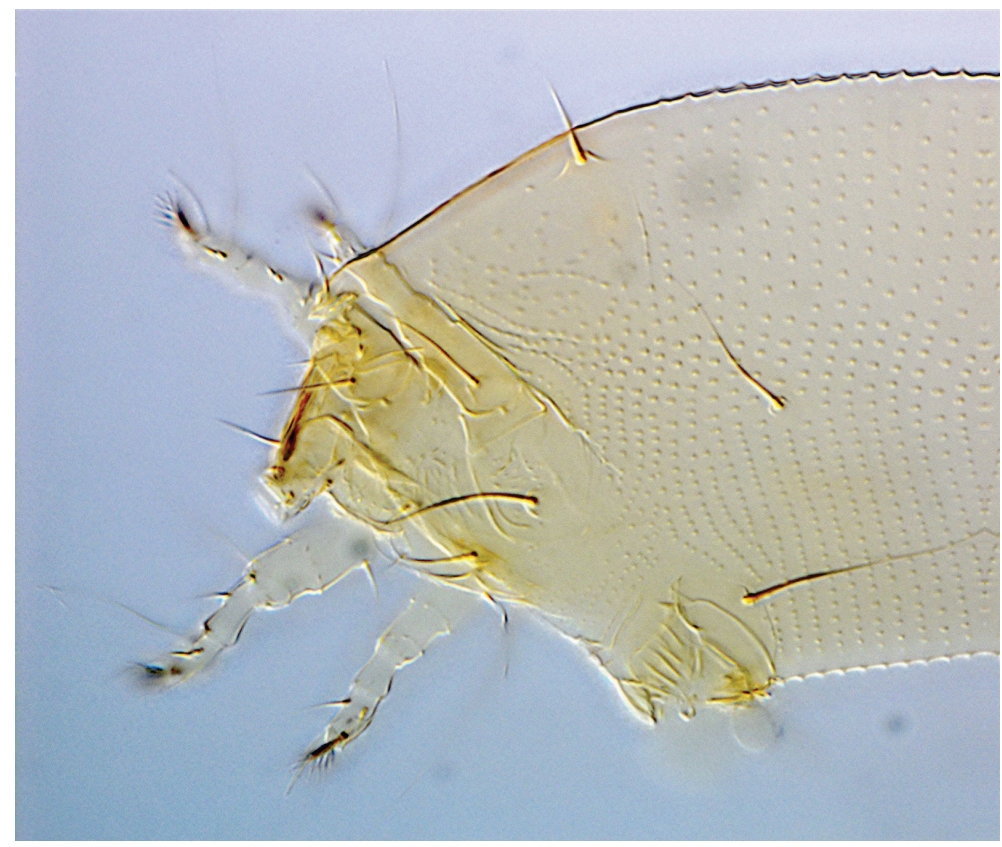

Fig. 9. Digital micrograph of Epitrimerus rubi, anterior part of female in lateral view (Photo: Árpád Szabó)

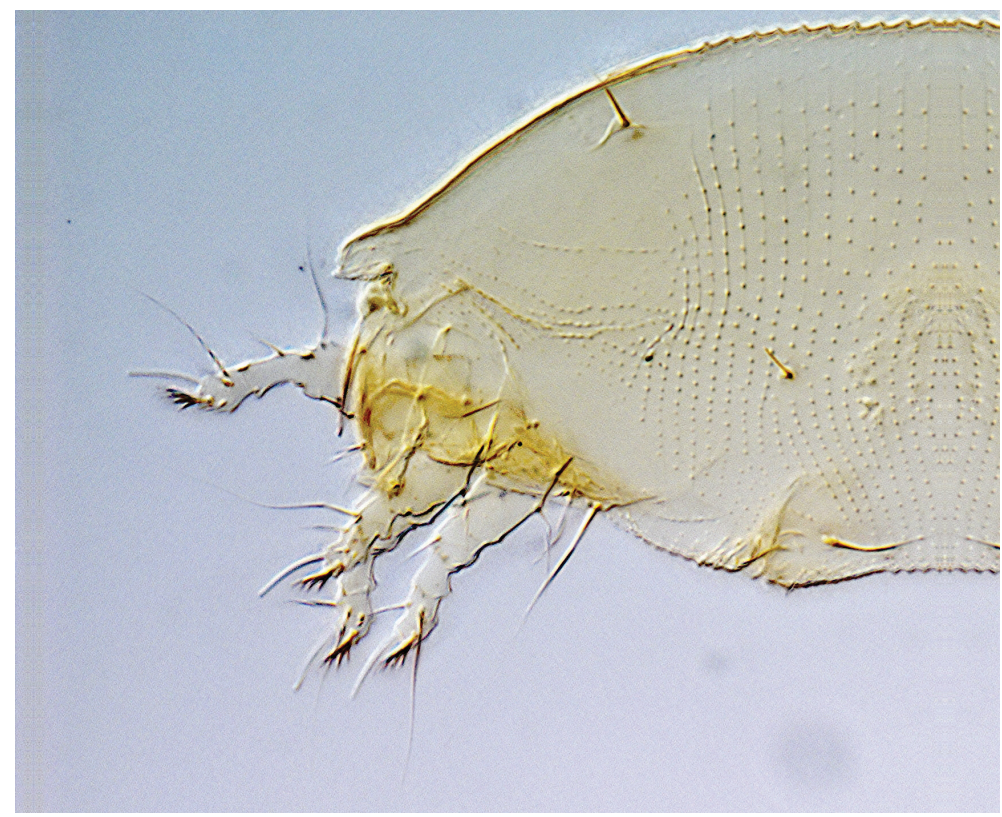

Fig. 10. Digital micrograph of Epitrimerus rubi, anterior part of male in lateral view (Photo: Árpád Szabó) 


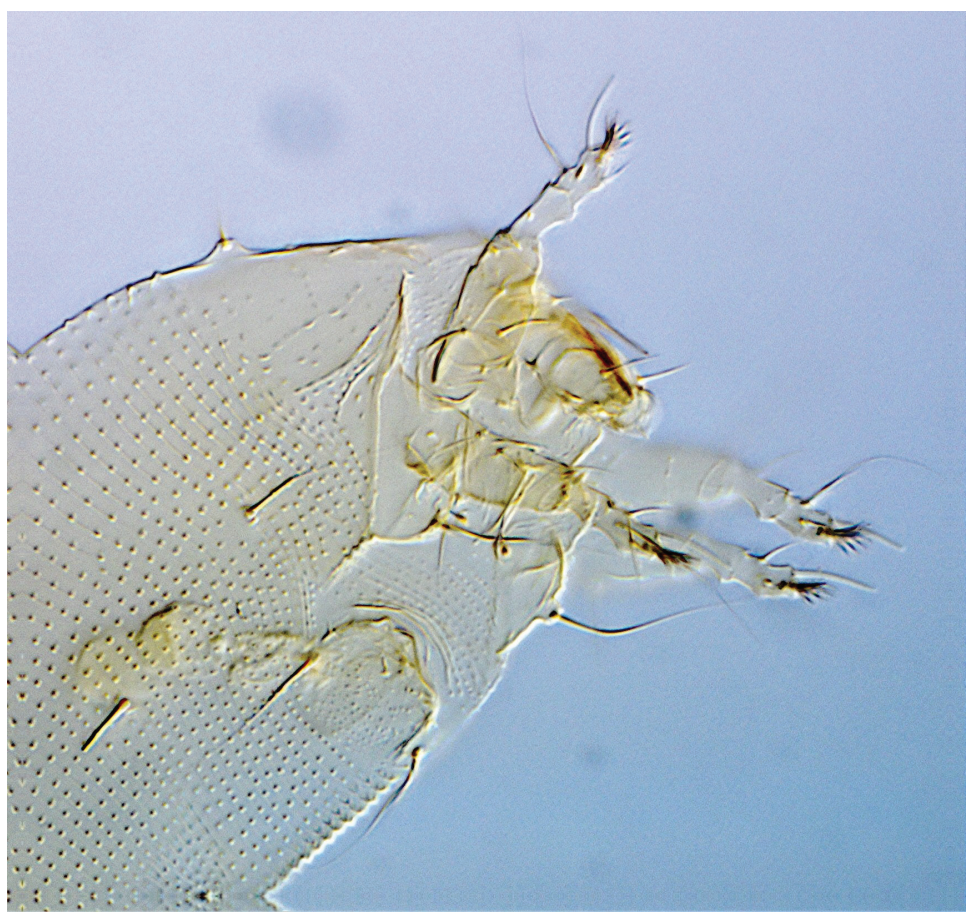

Fig. 11. Digital micrograph of Epitrimerus rubi, anterior part of male in ventrolateral view (Photo: Árpád Szabó)

verging to rear margin, two incomplete and faint submedian lines; laterally microgranules between the submedian and the shield margin, posteriorly irregular faint granules between the tubercles of scapular setae sc. All lines ridges bearing rounded microtubercles. Prodorsal shield pattern considerably variable, e.g. number, size and position of lines and microgranules differ on the examined specimens. Tubercles of scapular setae $s c$ ahead 6 (5-7) of rear shield margin, 15 (15-16) apart, scapular setae sc 9 (7-11), directed up and centrad. Minute granules situated in lateral rows on epicoxal areas, i.e. laterally between shield margin and dorsal coxae of legs I and II.

Legs with all usual segments and setae present. Leg I 32 (30-35), femur 9 (8-10), basiventral femoral seta $b v 11(10-12)$, genu 5 (5-6), antaxial genual seta $l$ " 21 (16-23), tibia 7 (6-8), paraxial tibial seta $l^{\prime}$ located at $2 / 5(2 / 5-1 / 2)$ from dorsal base, $6(4-7)$, very thin, tarsus 7 (6-8), unguinal tarsal seta $u^{\prime} 4(3-4)$, solenidion $\omega 8$ (7-9), distally rounded or with a minute knob, slightly curved, empodium simple, bilaterally symmetrical, 6 (5-6), 4-rayed.

Leg II 29 (28-31), femur 10 (9-10), basiventral femoral seta bv 12 (9-13), genu 5 (no range), antaxial genual seta $l$ " $6(5-7)$ very thin, tibia 5 (4-5), tarsus 7 (6-7), unguinal tarsal seta $u^{\prime} 4(3-4)$, solenidion $\omega 8$ (8-9), distally rounded or with a minute knob, slightly curved, empodium simple, bilaterally symmetrical, 6 (5-6), 4-rayed. Tiny spinules distally on femur and genu on both leg pairs.

Coxigenital area with 4-8 faint microtuberculate semiannuli. Coxisternae I with faint longitudinal lines of granules, coxisternae II with faint transverse lines of granules and dashes; anterior seta on coxisternum I, seta $1 b 4$ (3-5), tubercles setae $1 b 11(10-11)$ 
apart, proximal seta on coxisternum I, seta 1 a 13 (12-16), tubercles $1 a 8$ (7-8) apart, proximal seta on coxisternum II, seta $2 a 27$ (25-30), tubercles $2 a 19$ (18-20) apart. Subcapitular plate shield-shaped, with granules. Prosternal apodeme 8 (7-9).

Opisthosoma with a median and two submedian ridges; with 58 (48-69) microtuberculate dorsal semiannuli, 71 (65-79) densely microtuberculate ventral semiannuli. Median ridge ends at dorsal annulus 37-38, or 12-13 from rear. Microtubercles minute and round ventrally, and slightly oval dorsally set on rear annular margin. Last 4-5 annuli with linear microtubercles on ventral side, and faint and elongate microtubercles dorsally. Opisthosomal setae $c 211$ (10-12), on annulus 11 (9-13); opisthosomal setae $d 37$ (32-45), on annulus 25 (22-29); opisthosomal setae e 29 (23-37), on annulus 46 (40-51); opisthosomal setae $f$ 23 (19-27), on annulus 66 (59-74), or 5 (5-6) from the rear. Opisthosomal setae $h 251$ (45$60)$, very thin at apex, opisthosomal setae $h 17$ (6-8). Anal lobes normal in size and shape.

Genital plate 15 (13-17), 19 (18-20) wide. Female genital coverflap with 2 transverse lines basally and 12 (11-13) longitudinal ridges; coxisternal III setae $3 a 15$ (14-15) apart, 14 (13-16), very thin. Internal genitalia: spermathecae ovoid, oriented posterolaterad; spermathecal tubes relatively short; anterior transverse genital apodeme trapezoidal, distinct, distally folded. (Figs 7, 8, 9, 10, 11).

MALE - Similar to female, 123-155 ( $\mathrm{n}=5)$, 45 wide, 45-57 thick. Gnathosoma 18-20, projecting obliquely downwards; chelicerae 15-16, dorsal palp genual setae $d$ 5-6, unbranched, pedipalp coxal setae ep 2-3. Prodorsal shield 40-43, 40-50 wide, semicircular, with an acuminate frontal lobe 5-7, shape and ornamentation similar to female. All lines ridges bearing rounded microgranules. Tubercles of scapular setae $s c$ ahead 5-7 of rear shield margin, scapular setae sc 6-7, directed up and centrad, 14-15 apart. Minute granules laterally in rows between shield margin and dorsal coxae of legs I and II. Legs with all usual segments and setae present. Leg I 28-30, femur 7-8, basiventral femoral seta $b v 8-10$, genu 5, antaxial genual seta $l^{\prime \prime} 18-20$, tibia 5-7, paraxial tibial seta $l^{\prime}$ located at $2 / 5-1 / 2$ from dorsal base, $5-7$, very fine, tarsus $6-8$, unguinal tarsal seta $u^{\prime} 3$, solenidion $\omega 7-8$, slightly curved, distally rounded or with a minute knob, empodium simple, bilaterally symmetrical, 5, with 4 paired rays. Leg II 25-28, femur 7-8, basiventral femoral seta $b v 10-12$, very fine, genu 4-5, antaxial genual seta $l^{\prime \prime} 5$, very fine, tibia $4-5$, tarsus 5-6, unguinal tarsal seta $u^{\prime} 3-4$, solenidion $\omega 8$, slightly curved, distally rounded or with a minute knob, empodium simple, bilaterally symmetrical, 5, with 4 paired rays. Tiny spinules distally on femur and genu on both leg pairs. Coxigenital area with 7-12 faint microtuberculate semiannuli. Coxisternum I with longitudinal lines of minute granules, coxisternum II with longitudinal and transverse lines of granules and dashes; anterolateral seta on coxisternum I, seta $1 b 3-5$, proximal seta on coxisternum I, seta $1 a 13-15$, proximal seta on coxisternum II, seta $2 a$ 23-25, all very fine. Subcapitular plate shield-shaped, with granules. Prosternal apodeme 7-8. Opisthosoma with 48-55 microtuberculate dorsal semiannuli, 58-72 microtuberculate ventral semiannuli. Median ridge ends at dorsal annulus $37-38$, or $12-13$ from rear. The microtubercles minute and round ventrally, and oval laterally set on rear annular margin except for 4-6 ventral semiannuli of anal lobes, which elongate and linear. Anal lobes normal in size and shape. Setae $c 2$ 9-10, on annulus 9-12; setae $d 28-36$, on annulus 20-25; setae $e$ 21-23, on annulus 35-42; setae $f 18-21$, on annulus 53-67, or 5-6 from rear. Setae $h 2$ 40-46; setae hl 5-6. Genitalia 13-15, 16-18 wide, with 1-2 transverse lines basally, with densely microgranules, in progenital chamber tiny eugenital setae present, setae $3 a$ 12-13. 
NYMPH - White, vermiform, $137(\mathrm{n}=1), 45$ thick. Gnathosoma 17. Prodorsal shield 30, semicircular with a frontal lobe 3. Setae sc 5; ahead 5 of rear shield margin, pointing up. Leg I 18, leg II 16 . Seta $l b 1$, seta $l a 3$, seta $2 a 9$, all very fine. Opisthosoma with 43 dorsal, 51 ventral semiannuli. Dorsal and ventral semiannuli with minute microtubercles on rear annular margin. Setae $c 25$, on annulus 9; setae $d 10$, on annulus 20; setae $e$ 9, on annulus 30; setae $f 10$, on annulus 46, or 5 from rear. Setae $h 13$; setae $3 a 5$.

Host plant - Rubus bertramii G. Braun (Fam. Rosaceae). The host plant has a West and Central European distribution from the British Isles to Austria, it grows on acidic soils, mainly in hedges and forest fringes. The species was sampled in Upper Austria at the south-eastern border of the range.

Relationship to the host - Females, males and nymph of E. rubi were collected from the dirty light green erinea, found on the lower surface of the leaves. The mites caused typical erinea on the host plant.

Locality - Austria, Upper Austria, Wolfern, 0,2 km N of Hainbach, forest fringes, 370 m a.s.1., N48.1256, E14.3454, 12 VII 2019, G. Király.

Material examined - the re-described female and described males and nymph among 2 females and 2 males on one slide, 12 July 2019, slide \# 1474a. Other specimens were collected - 2 slides (\# 1474b, \# 1474c) from the same host, in the same locality and date, containing (\# 1474b) 9 females, 5 males and one larva, and (\# 1474c) 3 females and 7 males. They are in the collection of G. Ripka and deposited in the National Food Chain Safety Office, Directorate of Plant Protection, Soil Conservation and Agri-environment, Hungary.

Epitrimerus rubi has 4-rayed empodium, whereas two other similar species, Epitrimerus gibbosus (Nalepa, 1892) and Epitrimerus vulgarubi Honarmand et al., 2019 have 5-rayed empodium. The erinea inducing E. rubi reached high population density on Rubus bertramii (Table 1), with considerably high ratio of males.

Epitrimerus gibbosus is a similar refuge-inhabiting species causing greyish-white erineum along veins on leaf under and upper side, and leaf margin. E. gibbosus was first reported in Hungary, as Eriophyes gibbosus, by Ambrus (1958) from Rubus fruticosa, R. idaeus, $R$. sp. and $R$. thyrsoideus. These records were apparently based on observed host damage symptoms alone, e.g. erineum and gall morphology, and not on the morphological characteristics of the mite species itself, and cannot be verified. Farkas (1966) confirmed E. gibbosus, also as Eriophyes gibbosus, from Rubus spp., and reported it as being a frequent species in Hungary. In the present study it was not a frequent Rubus-dwelling species (Table 1). E. gibbosus was found in considerably high numbers on the underside of the leaves of Rubus ser. Subcanescentes H.E. Weber near Nemesvámos (Hungary). It was difficult to pick the light ochre mites out among the erineum trichomes. E. gibbosus caused mosaic-like greenish-yellow spots on the leaves between and along the veins.

\section{Genus Phyllocoptes Nalepa Phyllocoptes gracilis (Nalepa, 1890)}

Cecidophyes gracilis Nalepa, 1890: 67.

Cecidophyes gracilis Nalepa, 1891: 385-387. Taf. 1, Figs 9-10. 
Phyllocoptes gracilis - Roivainen, 1953: 26-27.

Eriophyes gracilis - Farkas, 1966: 72.

Phyllocoptes gracilis - Amrine and Stasny, 1994: 187, 633.

Phyllocoptes gracilis was first reported in Hungary, as Eriophyes gracilis, by Farkas (1966). He described it, and mentioned the damage symptoms caused by the species as whitish spots and leaf torsion. According to Roivainen (1953) who transferred this species from the genus Eriophyes to Phyllocoptes, P. gracilis is a vagrant mite living on the under surface of the leaves. On the other hand Dobrivojević and Petanović (1985) and Domes (1957) gave detailed description of the female and the pronounced symptoms on raspberry caused by $P$. gracilis. Dobrivojević and Petanović (1985) reported the symptoms as light green to yellow spots, leaf discoloration, mottling, shoot proliferation, fruitfulness, and the natural pubescence was lost on the leaf underside. They stated that P. gracilis was a monophagous species. These leaf symptoms are often attributed to virus. In case of severe infestation the berries may ripen prematurely and dry up (Pye and de Lillo, 2010; Denizhan et al., 2015). Farkas (1966) reported a similar Rubus-inhabiting species, Phyllocoptes rubi Roivainen, 1950 from Hungary, as well, which caused no damage on the leaves of the host. It has 4-rayed empodium, whereas $P$. gracilis has 5-rayed empodium.

In this survey $P$. gracilis was collected from 8 bramble taxa (Rubus bifrons, $R$. caesius, $R$. clusii, $R$. grabowskii, $R$. montanus, Rubus ser. Rhamnifolii, $R$. slavonicus and $R$. solvensis) in Austria and Hungary, and was the most frequent eriophyoid species on Rubus spp. (Table 1). It was found in remarkably high numbers on Rubus clusii. P. gracilis coexisted with Anthocoptes rubicolens on Rubus bifrons, $R$. grabowskii, Rubus ser. Rhamnifolii, R. slavonicus and R. solvensis in Hungary and Austria (Table 3). According to our results, both A. rubicolens and $P$. gracilis are oligophagous species feeding on several members of the genus Rubus. Based on our survey Rubus bertramii, R. clusii, $R$. grabowskii, $R$. montanus, $R$. praecocifrons, $R$. praecox, $R$. ser. Rhamnifolii, $R$. slavonicus, $R$. solvensis and $R$. ser. Subcanescentes proved to be new host plants for eriophyoid mites (Tables 1 and 3 ).

To the authors' knowledge, in Central Europe the present work represents the first attempt to discover the eriophyoid mite fauna having limited ambulatory dispersal capabilities of 14 Rubus taxa in different natural and seminatural habitats.

\section{Family Phytoseiidae Berlese}

The present study provides new data to the acarine biodiversity on the foliage of Rubus spp. excluding the cultivated fruit crops (e.g. European blackberry and raspberry). A total of four phytoseiid mite species (Acari: Parasitiformes: Phytoseiidae) were identified. On majority of our bramble leaf samples Phytoseius juvenis was present in considerably high numbers. It was identified from 12 Rubus taxa, while the other three species, Amblyseius andersoni, Anthoseius rhenanus and Neoseiulus cucumeris (Oudemans) were collected only from one Rubus species and in one locality (Tables 2 and 3). In Hungary A. andersoni had been recorded from raspberry (Komlovszky and Jenser, 1987). Szabó et al. (2010, 2013) reported P. juvenis with the highest population density from Rubus spp. in Eger and Badacsony wine growing regions. (Figs 12, 13, 14, 15, 16). 


\section{Table 1}

Eriophyoid mite species collected from Rubus species

\begin{tabular}{|c|c|c|c|}
\hline Mite species & Host species & Locality & Date of collection \\
\hline \multirow{9}{*}{$\begin{array}{l}\text { *Anthocoptes } \\
\text { rubicolens } \\
\text { Roivainen, } 1953\end{array}$} & Rubus bifrons Vest & Sopronkövesd (Hungary) & 14 July 2019 \\
\hline & - Rubus clusii Borbás & Winklarn (Austria) & 12 July 2019 \\
\hline & - Rubus clusii Borbás & Sopronkövesd (Hungary) & 14 July 2019 \\
\hline & - Rubus grabowskii Weihe & Ansfelden (Austria) & 12 July 2019 \\
\hline & - Rubus ser. Rhamnifolii (Bab.) Focke & Maria Taferl (Austria) & 12 July 2019 \\
\hline & - Rubus praecocifrons Király et Trávn. & Sopronkövesd (Hungary) & 14 July 2019 \\
\hline & - Rubus praecox Bertol. & Sopronkövesd (Hungary) & 14 July 2019 \\
\hline & - Rubus slavonicus Király, Trávn. et Žila & Várvölgy (Hungary) & 8 August 2019 \\
\hline & - Rubus solvensis W. Maurer & Kétvölgy (Hungary) & 30 August 2019 \\
\hline \multirow{3}{*}{$\begin{array}{l}\text { Epitrimerus } \\
\text { gibbosus } \\
\text { (Nalepa, 1892) }\end{array}$} & Rubus bifrons Vest & Sopronkövesd (Hungary) & 14 July 2019 \\
\hline & Rubus caesius $\mathrm{L}$. & Sopronkövesd (Hungary) & 14 July 2019 \\
\hline & Rubus ser. Subcanescentes H.E.Weber & Nemesvámos (Hungary) & 8 August 2019 \\
\hline $\begin{array}{l}\text { Epitrimerus rubi } \\
\text { (Domes, 1960) }\end{array}$ & - Rubus bertramii G. Braun & Wolfern (Austria) & 12 July 2019 \\
\hline \multirow{9}{*}{$\begin{array}{l}\text { Phyllocoptes } \\
\text { gracilis } \\
\text { (Nalepa, 1890) }\end{array}$} & Rubus bifrons Vest & Sopronkövesd (Hungary) & 14 July 2019 \\
\hline & Rubus caesius L. & Sopronkövesd (Hungary) & 14 July 2019 \\
\hline & • Rubus clusii Borbás & Winklarn (Austria) & 12 July 2019 \\
\hline & • Rubus clusii Borbás & Sopronkövesd (Hungary) & 14 July 2019 \\
\hline & - Rubus grabowskii Weihe & Ansfelden (Austria) & 12 July 2019 \\
\hline & - Rubus montanus Lib. ex Lej. & Ansfelden (Austria) & 12 July 2019 \\
\hline & - Rubus ser. Rhamnifolii (Bab.) Focke & Maria Taferl (Austria) & 12 July 2019 \\
\hline & - Rubus slavonicus Király, Trávn. et Žila & Várvölgy (Hungary) & 8 August 2019 \\
\hline & - Rubus solvensis W. Maurer & Kétvölgy (Hungary) & 30 August 2019 \\
\hline
\end{tabular}

$*=$ new species for the Hungarian fauna, $\bullet=$ new host species. 


\section{Table 2}

Phytoseiid mite species collected from Rubus species

\begin{tabular}{|c|c|c|c|}
\hline Mite species & Plant species & Locality & Date of collection \\
\hline $\begin{array}{l}\text { Amblyseius andersoni } \\
\text { (Chant, 1957) }\end{array}$ & $\begin{array}{l}\text { Rubus slavonicus Király, } \\
\text { Trávn. et Žila }\end{array}$ & Várvölgy (Hungary) & 8 August 2019 \\
\hline $\begin{array}{l}\text { Anthoseius rhenanus } \\
\text { (Oudemans, 1905) }\end{array}$ & Rubus caesius L. & Sopronkövesd (Hungary) & 14 July 2019 \\
\hline $\begin{array}{l}\text { Neoseiulus cucumeris } \\
\text { (Oudemans, 1930) }\end{array}$ & - Rubus solvensis W. Maurer & Kétvölgy (Hungary) & 30 August 2019 \\
\hline \multirow{13}{*}{$\begin{array}{l}\text { Phytoseius juvenis } \\
\text { Wainstein et Arutunjan, } 1970\end{array}$} & - Rubus bertramii G. Braun & Wolfern (Austria) & 12 July 2019 \\
\hline & - Rubus bifrons Vest & Sopronkövesd (Hungary) & 14 July 2019 \\
\hline & Rubus caesius $\mathrm{L}$. & Sopronkövesd (Hungary) & 14 July 2019 \\
\hline & - Rubus clusii Borbás & Winklarn (Austria) & 12 July 2019 \\
\hline & - Rubus clusii Borbás & Sopronkövesd (Hungary) & 14 July 2019 \\
\hline & - Rubus grabowskii Weihe & Ansfelden (Austria) & 12 July 2019 \\
\hline & - Rubus montanus Lib. ex Lej. & Ansfelden (Austria) & 12 July 2019 \\
\hline & $\begin{array}{l}\text { Rubus praecocifrons Király } \\
\text { et Trávn. }\end{array}$ & Sopronkövesd (Hungary) & 14 July 2019 \\
\hline & - Rubus praecox Bertol. & Sopronkövesd (Hungary) & 14 July 2019 \\
\hline & $\begin{array}{l}\text { Rubus ser. Rhamnifolii } \\
\text { (Bab.) Focke }\end{array}$ & Maria Taferl (Austria) & 12 July $2019 m$ \\
\hline & $\begin{array}{l}\text { Rubus slavonicus Király, } \\
\text { Trávn. et Žila }\end{array}$ & Várvölgy (Hungary) & 8 August 2019 \\
\hline & - Rubus solvensis W. Maurer & Kétvölgy (Hungary) & 30 August 2019 \\
\hline & $\begin{array}{l}\text { Rubus wimmerianus (Sudre) } \\
\text { Sprib. }\end{array}$ & Rimavská Baňa (Slovakia) & 20 August 2019 \\
\hline
\end{tabular}

$\bullet=$ new plant species. 


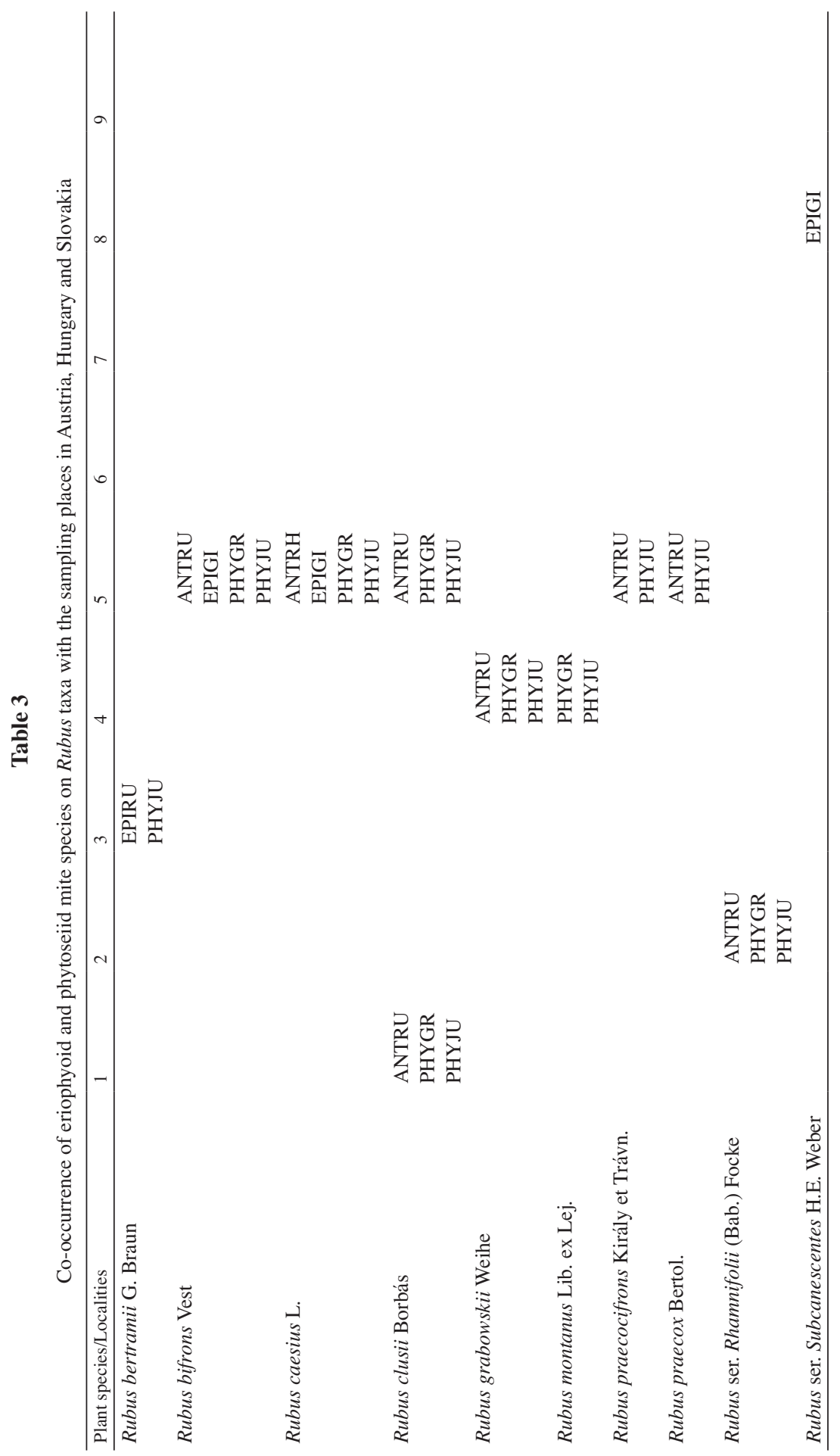




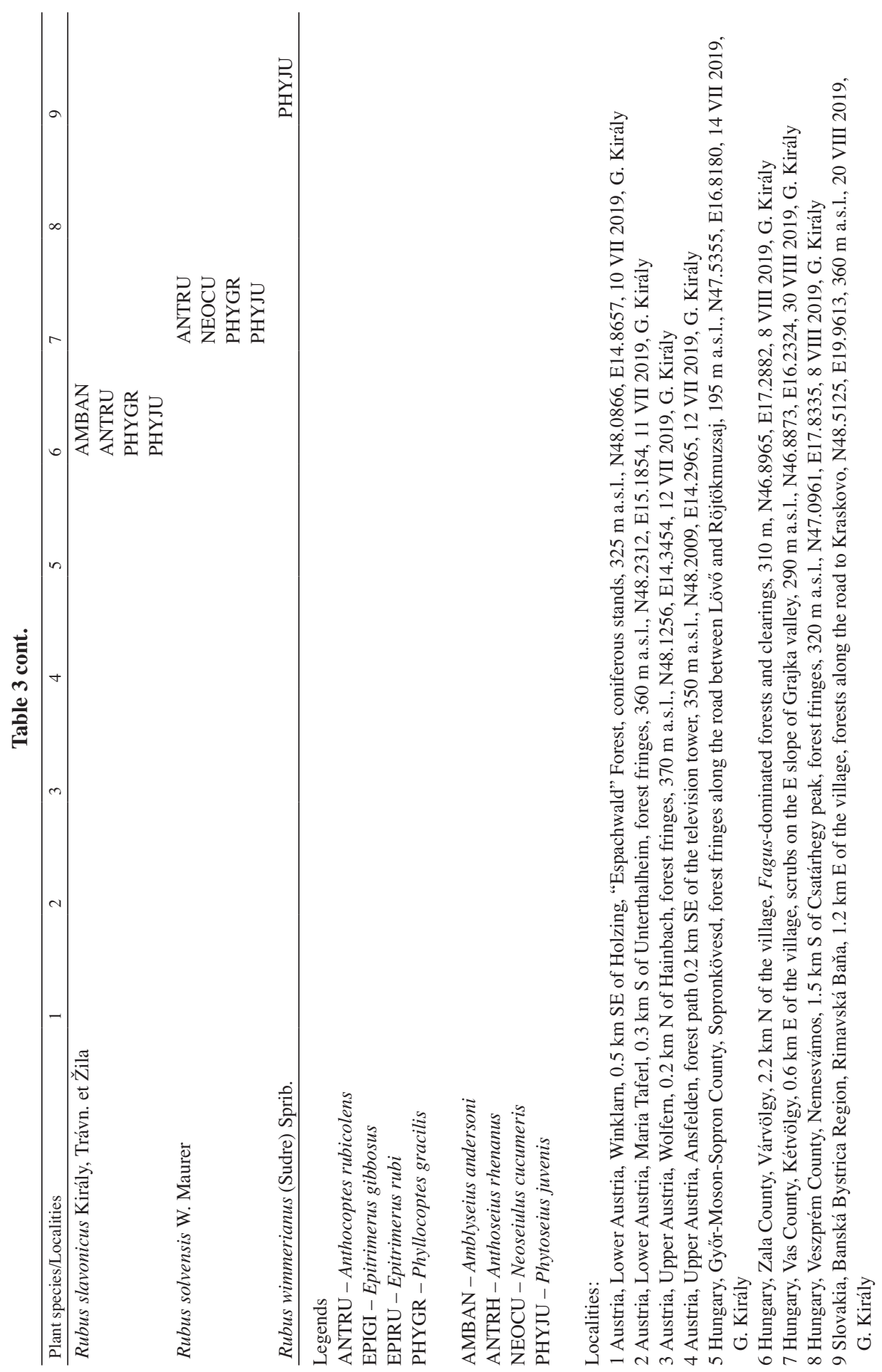




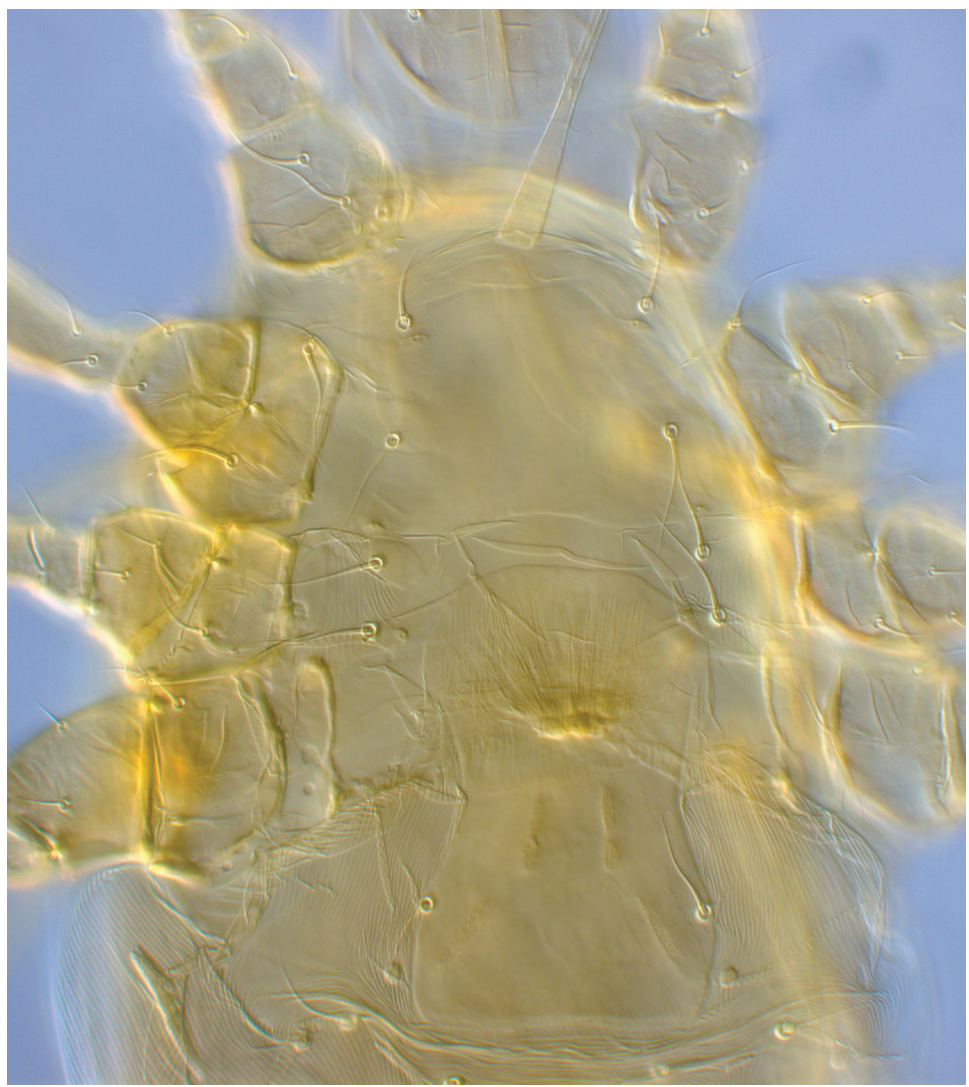

Fig. 12. Digital micrograph of Phytoseius juvenis, female idiosoma in ventral view (Photo: Árpád Szabó)

\section{Discussion}

In Serbia, out of 21 bramble-inhabiting phytoseiid species, seven Phytoseius species were reported from 8 Rubus taxa, viz. Phytoseius canadensis (Chant), P corniger Wainstein, P. echinus Wainstein et Arutunjan, P. juvenis, P. macropilis, P. maltshenkovae Wainstein and P. ribagai Athias-Henriot (Stojnić et al., 2018). Out of the phytoseiid species, $P$. juvenis was the third most frequent species, without host data (Stojnić et al., 2018). In Europe, P. juvenis was reported from Rubus idaeus and Rubus spp. plants (Tuovinen, 1993, Tixier et al., 2000; Salmane and Petrova, 2002). In the present study, P. juvenis co-occurred with four eriophyid and three phytoseiid species (Table 3). The members of the genus Phytoseius are primarily generalist predators that live mainly on plants with pubescent leaves (McMurtry et al., 2013), as in case of several Rubus species. Based on our survey, phytoseiid mites have been recorded for the first time from Rubus bertramii, $R$. bifrons, $R$. clusii, $R$. grabowskii, $R$. montanus, $R$. praecocifrons, $R$. praecox, $R$. ser. Rhamnifolii, $R$. slavonicus, $R$. solvensis and $R$. wimmerianus (Tables 2 and 3 ).

Besides, tetranychid, tydeid, cunaxid and tarsonemid mites (all Acari: Acariformes) were also collected in our survey, which will be reported in a separate paper. 


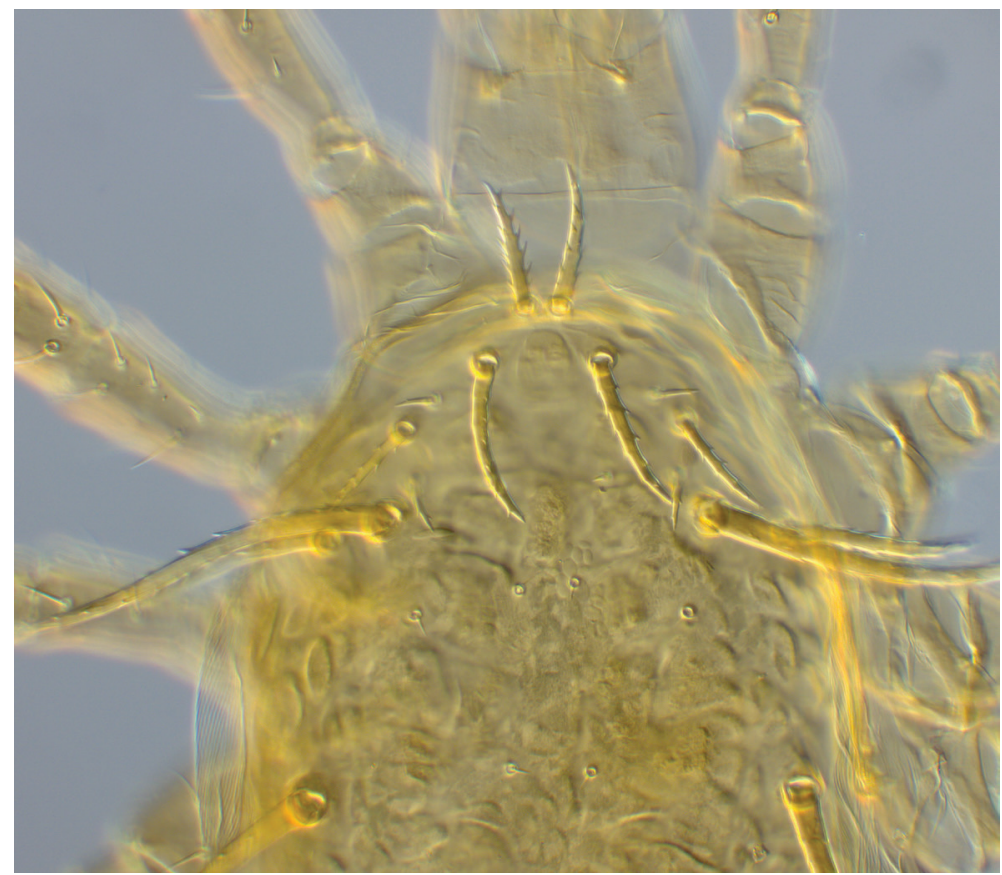

Fig. 13. Digital micrograph of Phytoseius juvenis, anterior part of female idiosoma in dorsal view (Photo: Árpád Szabó)

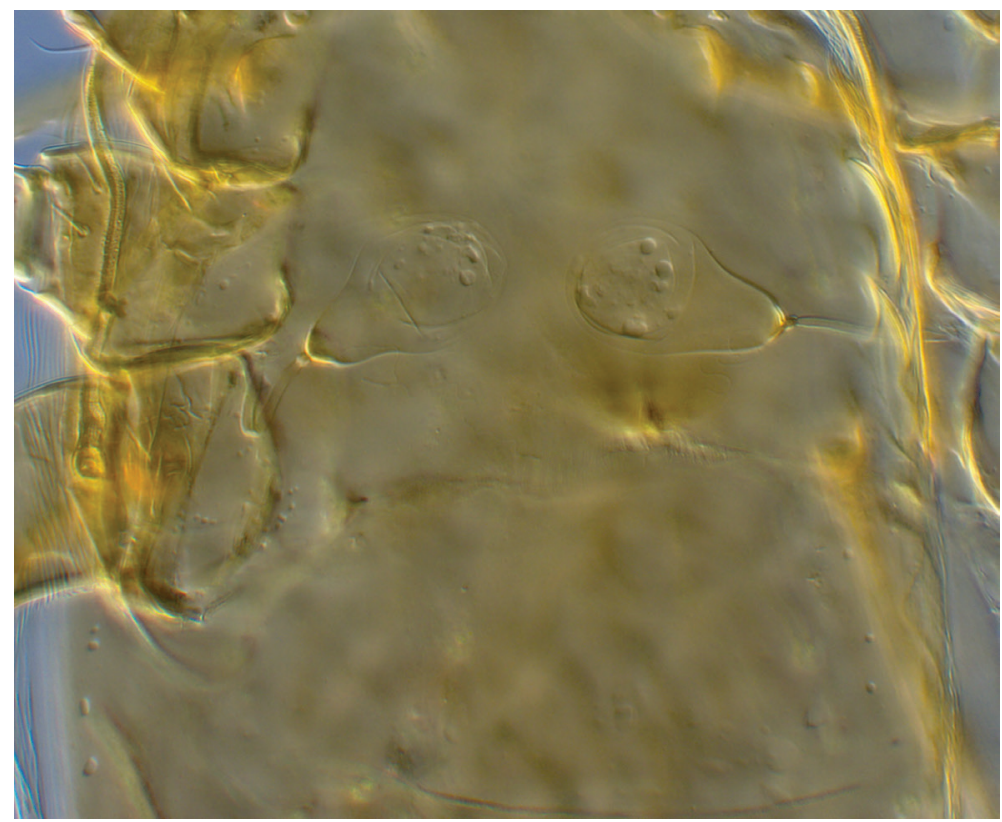

Fig. 14. Digital micrograph of Phytoseius juvenis, spermathecae of female (Photo: Árpád Szabó) 


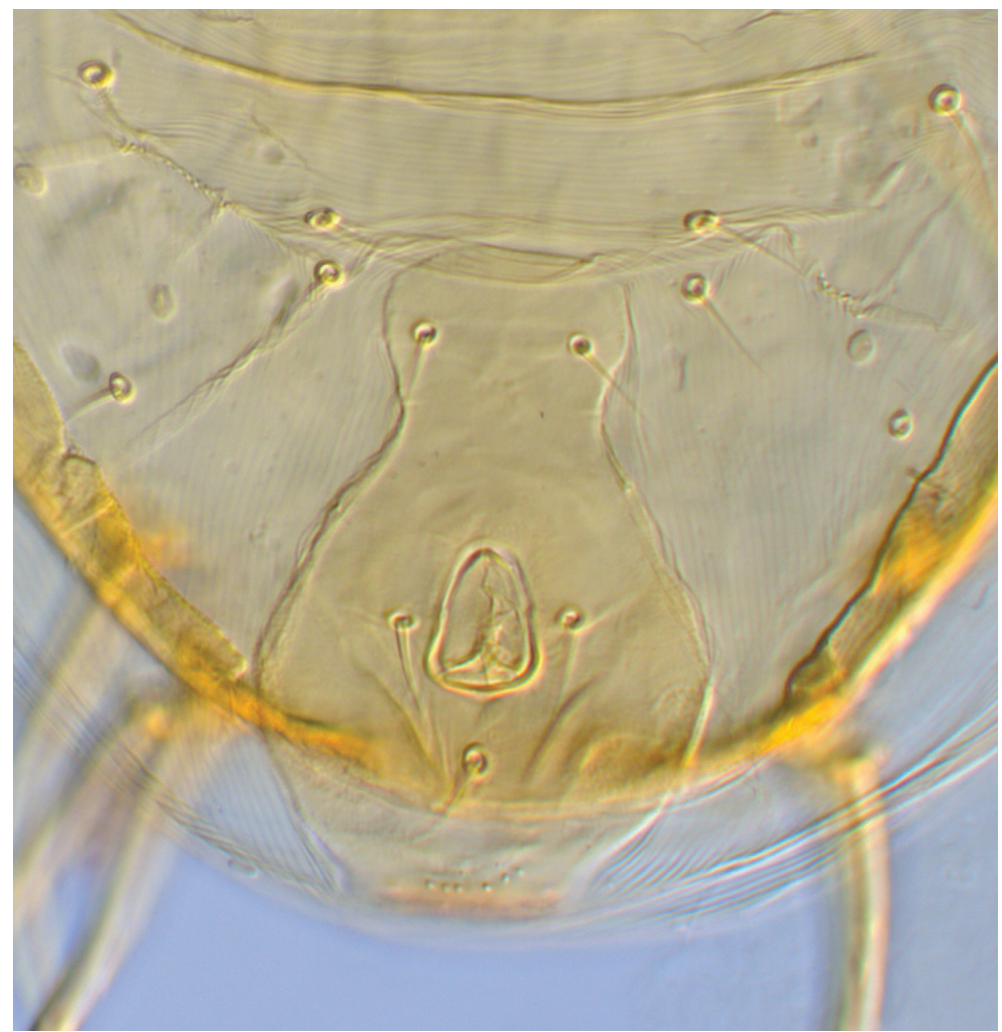

Fig. 15. Digital micrograph of Phytoseius juvenis, ventroanal shield of female (Photo: Árpád Szabó)

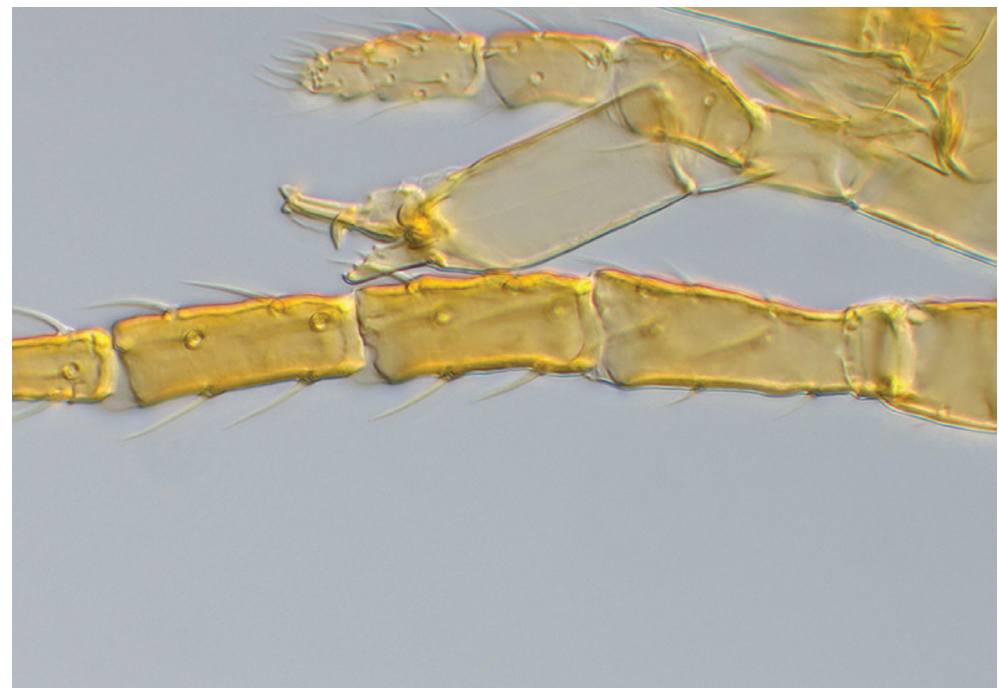

Fig. 16. Digital micrograph of Phytoseius juvenis, male chelicera with spermatodactyl (Photo: Árpád Szabó) 


\section{Acknowledgement}

The authors are indebted to Mr. Ede Böszörményi (National Food Chain Safety Office, Directorate of Plant Protection, Soil Conservation and Agri-environment, Budapest) for linguistic revision of an earlier manuscript draft.

\section{Literature}

Ambrus, B. (1958): Állatföldrajzi vizsgálatok Sopron és környékének gubacsfaunáján. (Zoogeographical bearings of the gall-nuts in Sopron and in its surroundings.) Állatt. Közlem. 46, 159-176. (In Hungarian with English summary).

Amrine, J. W. Jr. and Stasny, T. A. H. (1994): Catalog of the Eriophyoidea (Acarina: Prostigmata) of the World. Indira Publishing House, West Bloomfield, U.S.A., ix + 798 p.

Amrine, J. W. Jr. and Manson, D. C. M. (1996): Preparation, mounting and descriptive study of eriophyoid mites. In: E. E. Lindquist, M. W. Sabelis and J. Bruin (eds): Eriophyoid Mites: Their Biology, Natural Enemies and Control. Elsevier, World Crop Pests, 6, pp. 383-396. https://doi.org/10.106/s1572-4379(96)80023-6

Amrine, J. W. Jr., Stasny, T. A. and Flechtmann, C. H. W. (2003): Revised Keys to World Genera of Eriophyoidea (Acari: Prostigmata). Indira Publishing House, West Bloomfield, U.S.A., pp. iv +244

Ayala-Ortega, J. J., Martínez-Castillo, A. M., Pineda-Guillermo, S., Figueroa-De La Rosa, J. I., Acuňa-Soto, J., Ramos-Lima, M. and Vargas-Sandoval, M. (2019): Mites associated with blackberry (Rubus sp. cv. Tupy) in two areas of Michoacan, Mexico. (Ácaros associados a la zarzamora (Rubus sp. cv. Tupy) en dos localidades del estado de Michoacán, México.) Revista Colombiana de Entomologia, 45, 1-10. https:// doi.org/10.25100/socolen.v45i2.8480

Baker, E. W., Kono, T., Amrine, J. W. Jr., Delfinado-Baker, M. and Stasny, T. A. (1996): Eriophyoid Mites of the United States. Indira Publishing House, West Bloomfield, U.S.A. pp. ix + 394

Bozai, J. (1996): Adalékok Magyarország ragadozóatka-faunájához (Acari: Phytoseiidae, Phytoseiinae). (Data to the knowledge of predaceous mites of Hungary (Acari: Phytoseiidae, Phytoseiinae).) Növényvédelem, 32, 521-525. (In Hungarian with English summary)

Canestrini, G. (1892): Prospetto dell' Acarofauna Italiana. Parte V. Famiglia dei Phytoptini. Atti della Societá Veneto-Trentina di Scienze naturali, Padova, 1, 543-722. + 16 pls.

Canestrini, G. (1894): Prospetto dell' Acarofauna Italiana. Parte VI. Appendice ai Fitoptidi italani. Atti della Societá Veneto-Trentina di Scienze naturali, Padova, 2, 723-833. + 18 pls.

Davis, R., Flechtmann, C. H. W., Boczek, J. H. and Barké, H. E. (1982): Catalogue of Eriophyid Mites (Acari: Eriophyoidea). Warsaw Agricultural University Press, Warsaw, 254 p.

Demite, P. R., Moraes, G. J. de, McMurtry, J. A., Denmark, H. A. and Castilho, R. C. (2020): Phytoseiidae Database. Available from: www.lea.esalq.usp.br/phytoseiidae (accessed 10/01/2020)

Denizhan, E., Monfreda, R., de Lillo, E. and Çobanoğlu, S. (2015): Eriophyoid mite fauna (Acari: Trombidiformes: Eriophyoidea) of Turkey: new species, new distribution reports and an updated catalogue. Zootaxa, 3991, 1-63. http://dx.doi.org/10.11646/zootaxa.3991.1.1

Dobrivojević, K. and Petanović, R. (1985): Eriofidna grinja lista maline Phyllocoptes gracilis (Nal.) (Eriophyoidea, Acarina) malo poznata štetočina u Jugoslaviji. (Eriophyid raspberry leaf mite, Phyllocoptes gracilis (Nal.) (Eriophyoidea, Acarina), an insufficiently known pest in Yugoslavia.). Zaštita Bilja, 36, 247-254.

Domes, R. (1957): Zur Biologie der Gallmilbe Eriophyes gracilis Nalepa. Zeitschrift für Angewandte Entomologie, 41, 411-424.

Domes, R. (1960): Eriophyes rubi n. sp. (Acarina, Eriophyidae) an Rubus caesius und Rubus thyrsoideus. Zeitschrift für Angewandte Entomologie, 46, 245-253.

Domes, R. (1962): Anthocoptes rubi n. sp. (Acar., Eriophyidae) an Rubus bifrons Vest. Zeitschrift für Angewandte Entomologie, 50, 343-349.

Domes, R. (1999): Four new species of Eriophyoidea on Prunus domestica, Rosa canina, Rubus caesius and Prunus padus: Rhinophytoptus domestica n. sp., Paraphytoptus rosae n. sp., Diptacus caesius n. sp., and Eriophyes padi n. sp. Acarologia, 40, 305-319. 
Duso, C. and Vettorazzo, E. (1999): Mite population dynamics on different grape varieties with or without phytoseiids released (Acari: Phytoseiidae). Experimental and Applied Acarology, 23, 741-763.

Farkas, H. (1966): Gubacsatkák - Eriophyidae. In: Fauna Hungariae: 81(18). [Gall Mites - Eriophyidae. In: Animals of Hungary]. Akadémiai Kiadó, Budapest, pp. 1-164.

Hassan, A. S. (1928): Biology of the Eriophyidae with special reference to Eriophyes tristriatus (Nalepa). Univ. Calif. Publications in Entomol. 4, 341-394.

Honarmand, A., Sadeghi-Namaghi, H. and de Lillo, E. (2019): Three new vagrant eriophyoid species (Acari: Trombidiformes: Eriophyoidea) associated to Rosaceae species from South Khorasan province, East Iran. Systematic and Applied Acarology, 24, 1841-1850. http://doi.org/10.11158/saa.24.10.4

Huang, K.-W. (2001): Eriophyoid mites of Taiwan: description of eighty-six species from the Tengchih Area (Acarina: Eriophyoidea). Bulletin of National Museum of Natural Science, 14, 1-84. (accessed 20 July 2018)

Huang, K.-W. and Wang, C.-F. (2009): Eriophyoid mites (Acari: Eriophyoidea) of Taiwan: thirty-seven species from Yangmingsah, including one new genus and twenty-two new species. Zootaxa, 1986, 1-50. (accessed 20 July 2018)

Keifer, H. H. (1959): Eriophyid Studies XXVIII. Occasional Papers, Cal. Dept. Agric., 2, 1-20.

Keifer, H. H. (1975): Eriophyoidea Nalepa. In: L. R. Jeppson, H. H. Keifer, and E. W. Baker (eds): Mites Injurious to Economic Plants. University of California Press, Berkeley, Los Angeles, London. pp. 327-533.

Király, G. (2018): Alien Rubus species in Hungary: distribution, habitats and threats. Dendrobiology, 80, 1-11. https://doi.org/10.12657/denbio.080.001

Király, G., Trávniček, B. and Žila, V. (2013): A szeder (Rubus L.) nemzetség modern taxonómiai koncepciója. (Modern Rubus taxonomy.) Erdészettudományi Közlemények, 3, 147-156. (In Hungarian with English summary)

Király, G., Trávniček, B. and Žila, V. (2015): Rubus gayeri and Rubus slavonicus, two new species of Rubus ser. Micantes (Rosaceae) from Central and South-Eastern Europe. Phytotaxa, 195, 279-290. http://dx.doi. org/10.11646/phytotaxa.195.4.3

Király, G., Sochor, M. and Trávniček, B. (2017): Reopening an old chapter: a revised taxonomic and evolutionary concept of the Rubus montanus group. Preslia, 89, 309-331. https://doi.org/10.23855/preslia.2017.309

Komlovszky, I. Sz. and Jenser, G. (1987): Az Amblyseius finlandicus Oudemans és a Phytoseius plumifer Canestrini et Fanzago ragadozó atkák gyakori előfordulása gyümölcsfákon. (The frequent occurrence of the predatory mites Amblyseius finlandicus Oudemans and Phytoseius plumifer Canestrini et Fanzago on fruit trees.) Növényvédelem, 23, 193-201. (In Hungarian with English summary)

Kuang, H. Y. (2001): Two new species of Diptacus from China. Entomotaxonomia, 23, 2, 153-156.

Kurtto, A. Weber, H. E., Lampinen, R. and Sennikov, A. N. (eds) (2010): Atlas Florae Europaeae. Distribution of vascular plants in Europe. 15. Rosaceae (Rubus). The Committee for Mapping the Flora of Europe and Societas Biologica Fennica Vanamo, Helsinki, 362 p.

Lindquist, E. E. (1996): External anatomy and notation of structures. In: E. E. Lindquist, M. W. Sabelis and J. Bruin (eds): Eriophyoid Mites: Their Biology, Natural Enemies and Control. Elsevier, World Crop Pests, 6, pp. 3-31. https://doi.org/10.106/S1572-4379(96)80003-0

McMurtry, J. A. and Show, E. D. (2012): Phytoseiidae on blackberry in Central California. Systematic and Applied Acarology, 17, 384-387. http://www.bioone.org/doi/full/10.11158/saa.17.4.6

McMurtry, J. A., Moraes, G. J. de and Sourassou, N. F. (2013): Revision of the lifestyles of phytoseiid mites (Acari: Phytoseiidae) and implications for biological control strategies. Systematic and Applied Acarology, 18, 297-321. http://dx.doi.org/10.11158/saa.18.4.1

Mo, Y., Lai, Y., Zhao, Y.-Y. and Wang, G.-Q. (2017): One new genus and three new species of Diptilomiopinae from Vietnam (Acari: Eriophyoidea). Systematic and Applied Acarology 22, 993-1011. http://doi. org/10.11158/saa.22.7.8

Moraes, G. J. de, McMurtry, J. A. and Denmark, H. A. (2004): A Catalog of the Mite Family Phytoseiidae. References to Taxonomy, Synonymy, Distribution and Habitat. EMBRAPA-DDT, Brasilia, $353 \mathrm{p}$.

Nalepa, A. (1890): Zur Systematik der Gallmilben. Sitzungsberichte der kaiserlichen Akademie der Wissenschaften. Mathematisch-naturwissenschaftliche Classe. Wien. Abtheilung 1, 99, 40-69. + 7 pls. 
Nalepa, A. (1891): Neue Gallmilben. Nova Acta Academiae Caesareae Leopoldino-Carolinae Germanicae Naturae Curiosorum. Verhandlungen der Kaiserlichen Leopoldinische-Carolinische Deutschen Akademie der Naturforscher. Halle, 55, 362-395. + 6 pls.

Nalepa, A. (1892): Neue Gallmilben. (5. Fortsetzung). Anzeiger der Kaiserlichen Akademie der Wissenschaften, Mathematische-naturwissenschaftliche Classe, Wien. 29, 190-192.

Nalepa, A. (1895): Beiträge zur Kenntniss der Gattungen Phytoptus Duj. und Monaulax Nal. Denkschriften der Kaiserlichen Akademie der Wissenschaften, Mathematische-naturwissenschaftliche Classe, Wien. 62, 627-640. + 4 pls.

Pye, D. L. R. and de Lillo, E. (2010): A review of the eriophyoid mites (Acari: Eriophyoidea) on Rubus spp. in Britain, with a new species (Diptilomiopidae) and new records. Zootaxa, 2677, 15-26. http://dx.doi. org/10.11646/zootaxa.2677.1.2

Ripka, G. (2007): Checklist of the eriophyoid mite fauna of Hungary (Acari: Prostigmata: Eriophyoidea). Acta Phytopathol. et Entomol. Hung. 42, 59-142. https://doi.org/10.1556/APhyt.42.2007.1.7

Ripka, G. and Szendrey, L-né G. (2003): Damage of new eriophyoid mites (Cecidophyopsis grossulariae [Collinge, 1907], Diptacus caesius Domes, 1999) for the Hungarian fauna on common gooseberry and blackberry. (Magyarország faunájára új Eriophyoidea atkafajok [Cecidophyopsis grossulariae (Collinge, 1907), Diptacus caesius Domes, 1999] kártétele köszmétén, illetve szedren.) Növényvédelem, 39, 449_ 451. (In Hungarian with English summary)

Ripka, G., Fain, A., Kaźmierski, A., Kreiter, S. and Magowski, W. Ł. (2005): New data to the knowledge of the mite fauna of Hungary (Acari: Mesostigmata, Prostigmata and Astigmata). Acta Phytopathol. et Entomol. Hung. 40, 159-176. http://dx.doi.org/10.1556/aphyt.40.2005.1-2.13

Roivainen, H. (1950): Eriophyid news from Sweden. Acta Entomol. Fennica, 7, 1-50.

Roivainen, H. (1953): Some gall mites (Eriophyidae) from Spain. Archivos del Instituto de Aclimatación, 1, $9-43$.

Salmane, I. and Petrova, V. (2002): Overview on Phytoseiidae mites (Acari, Mesostigmata, Gamasina) of Latvia. Latvijas Entomologs, 39, 48-54.

Sochor, M., Vašut, R. J., Sharbel, T. F. and Trávníček, B. (2015): How just a few makes a lot: Speciation via reticulation and apomixis on example of European brambles (Rubus subgen. Rubus, Rosaceae). Molecular Phylogenetics and Evolution, 89, 13-27. https://doi.org/10.1016/j.ympev.2015.04.007

Sochor, M., Trávniček, B. and Király, G. (2019): Ploidy level variation in the genus Rubus in the Pannonian Basin and the northern Balkans, and evolutionary implications. Plant Systematics and Evolution, 305, 611-626. https://doi.org/10.1007/s00606-019-01593-3

Stojnić, B., Mladenović, K. and Marčić, D. (2018): Species composition of spider mites and predatory mites (Acari: Tetranychidae, Phytoseiidae) on Rubus spp. in Serbia. Integrated control of plant-feeding mites. IOBC WPRS Bulletin, 134, 79-81.

Szabó, Á., Tempfli, B. and Pénzes, B. (2010): The occurrence of predatory mites in the Eger wine region, Hungary. (Ragadozó atkák előfordulása az Egri borvidéken.) Növényvédelem, 46, 1-9. (In Hungarian with English summary)

Szabó, Á., Varga, M. and Pénzes, B. (2013): The occurrence of predatory mites in the Badacsony wine region, Hungary. (Ragadozó atkák előfordulása a Badacsonyi borvidéken.) Növényvédelem, 49, 57-62. (In Hungarian with English summary)

Tajmiri, P. and Hajizadeh, J. (2014): Some mesostigmatic mites on raspberry shrubs (Rubus spp.) in central area of Guilan Province, Iran. J. Plant Protection Research, 2, 15-25.

Tixier, M.-S., Kreiter, S., Auger, P., Sentenac, G., Salva, G. and Weber, M. (2000): Phytoseiid mite species located in uncultivated areas surrounding vineyards in three French regions. Acarologia, 41, 127-140.

Trinidad, C. T. O., Duarte, M. E., Silva da Cunha, U. and Navia, D. (2018): Eriophyoid mites associated with the blackberry in Brazil - a new species in the genus Diptacus Keifer 1951 (Diptilomiopidae) and first report and supplementary description of Acalitus orthomerus (Keifer, 1951) (Eriophyidae). Systematic and Appl. Acarology, 23, 1199-1216. http://doi.org/10.11158/saa.23.6.15

Tuovinen, T. (1993): Identification and occurrence of phytoseiid mites (Gamasina: Phytoseiidae) in Finnish apple plantations and their surroundings. Entomol. Fennica, 4, 95-114.

Upton, M. S. (1991): Methods for Collecting, Preserving, and Studying Insects and Allied Forms. Misc. Publ. No. 3. The Australian Entomol. Society, Brisbane, v +86 p. 
Wang, Z., Xue, X.-F. and Hong, X.-Y. (2009): Four new species and a re-described species of the Diptilomiopinae (Acari: Eriophyoidea: Diptilomiopidae) from China. International J. Acarology, 35, 123-132. http:// doi.org/10.11158/saa.23.6.15

Weber, H. E. (1995): Rubus. In: H. E. Weber (ed.): Gustav Hegi, Illustrierte Flora von Mitteleuropa. Blackwell Wissenschafts-Verlag, Berlin, Oxford etc. ed. 3, Vol. 4/2A: 284-595.

Xin, J.-L. and Dong, H.-Q. (1983): Three new species of diptilomiopid mites found in China (Acarina: Eriophyoidea). Acarologia, 24, 181-185.

Xue, X.-F. and Hong, X.-Y. (2005): Five new species of Diptilomiopidae from China (Acari: Eriophyoidea). Zootaxa, 1055, 49-59.

Open Access statement. This is an open-access article distributed under the terms of the Creative Commons Attribution 4.0 International License (https://creativecommons.org/licenses/by/4.0/), which permits unrestricted use, distribution, and reproduction in any medium, provided the original author and source are credited, a link to the CC License is provided, and changes - if any - are indicated. (SID_1) 